NBER WORKING PAPER SERIES

ETHNICTTY, NEIGHBORHOODS, AND

HUMAN CAPITAL EXTERNALITIES

George J. Borjas

Working Paper No. 4912

\author{
NATIONAL BUREAU OF ECONOMIC RESEARCH \\ 1050 Massachusetts Avenue \\ Cambridge, MA 02138 \\ November 1994
}

I am grateful to Julian Betts, Thomas MaCurdy, James Rauch, Glenn Sueyoshi, Stephen Trejo, and Finis Welch for helpful comments, and to the National Science Foundation and the Russell Sage Foundation for financial support. This paper is part of NBER's research program in Labor Studies. Any opinions expressed are those of the author and not those of the National Bureau of Economic Research.

() 1994 by George J. Borjas. All rights reserved. Short sections of text, not to exceed two paragraphs, may be quoted without explicit permission provided that full credit, including $($ ) notice, is given to the source. 
NBER Working Paper \#4912

November 1994

\title{
ETHNICITY, NEIGHBORHOODS, AND \\ HUMAN CAPITAL EXTERNALITIES
}

\begin{abstract}
The socioeconomic performance of today's workers depends not only on parental skills, but also on the average skills of the ethnic group in the parent's generation (or ethnic capital). This paper investigates the link between the ethnic extemality and ethnic neighborhoods. The evidence indicates that residential segregation and the external effect of ethnicity are linked, partly because ethnic capital summarizes the socioeconomic background of the neighborhood where the children were raised. Ethnicity has an extemal effect, even among persons who grow up in the same neighborhood, when children are exposed frequently to persons who share the same ethnic background.
\end{abstract}

George J. Borjas

Department of Economics, 0508

University of California, San Diego

9500 Gilman Drive

La Jolla, CA 92093

and NBER 


\section{ETHNICITY, NEIGHBORHOODS, AND HUMAN CAPITAL EXTERNALITIES}

\section{George J. Borjas}

Ethnic neighborhoods have long been a dominant feature of American cities (and of cities in many other countries). In fact, segregation by race and ethnicity often defines the invisible line that creates a neighborhood. These neighborhoods insulate people of similar backgrounds, and foster a set of cultural attitudes, social contacts, and economic opportunities that affect workers throughout their lives.

In earlier work (Borjas, 1992, 1994), I have argued that ethnicity has an external effect on the human capital accumulation process. ${ }^{1}$ Persons raised in advantageous ethnic environments will be exposed to social and economic factors that increase their productivity, and the larger or more frequent the amount of this exposure, the higher the resulting "quality" of the worker.

As with the models that dominate the new growth literature, sufficiently strong ethnic externalities may delay the convergence of ethnic differentials indefinitely. My earlier empirical work indicated that the earnings of children are affected strongly not only by parental earnings as in the usual models of intergenerational income mobility, but also by the mean earnings of the ethnic group in the parent's generation (which I called "ethnic capital"). As a result, the ethnic spillover effect retards intergenerational improvement for relatively disadvantaged ethnic groups, and slows down the deterioration of skills (i.e., the regression lowards the mean) among the more advantaged groups.

\footnotetext{
${ }^{1}$ The importance of human capital extemalities in inlergenerational mobility was stressed in the early' work of John Conlisk (1977) and Glenn C. Loury (1977), who uses the concepl of "social capital" 10 analyze how racial discrimination influences the social mobility of blacks. Shelly Lundberg and Richard Stariz (1992) investigate how human capital extemalities may alter the impact of anidiscriminalion programs on social mobility.
} 
The process through which the ethnic externalities are transmitted, however, is not well understood. This paper investigates one possible mechanism, ethnic neighborhoods. The insight that human capital externalities and geography are linked is not new. In his pathbreaking work, Robert E. Lucas (1988) cites the crowding of similarly skilled workers into a small number of city blocks as a key determinant of the economic development of cities. Similarly, William Julius Wilson's (1987) influential work on the creation and growth of the underclass argues that blacks who live in poor neighborhoods are not exposed to "mainstream" role models, thus hampering the economic mobility of blacks.

This paper presents an empirical study of the link between geography and ethnic externalities. The analysis uses the $1 / 100$ Neighborhood File of the 1970 Public Use Sample of the U.S. Census and a specially-designed version of the National Longitudinal Surveys of Youth (NLSY). The Census data groups workers into one of over 40,000 neighborhoods, while the NLSY file groups workers into one of 1,978 zip codes. Hence it is possible to determine the extent to which ethnic groups segregate in particular neighborhoods, and the impact of this segregation on the process of human capital accumulation and intergenerational mobility. ${ }^{2}$

The main finding of the analysis is that residential segregation and the influence of ethnic capital on the process of intergenerational mobility are intimately linked. In particular, the impact of ethnic capital on the skills of the next generation arises partly because the ethnic capital variable is an excellent proxy for the socioeconomic background of the neighborhood where the children

\footnotetext{
2The role played by neighborhood effects in determining sociceconomic outconcs is currently the subject of intensive research; see, for instance, the survey of Christopher Jencks and Susan E. Meyer (1990) and the critical appraisal by Charles F. Manski (1993). Empirical evidence linking neighborhood effects to teenage pregnancy, criminal behavior, educational attainment, and human capital accumulation is given by Anne C. Case and Lawrence F. Katz (1991), Mary Corcoran, Roger Gordon, Deborah Laren and Gary Solon (1992), Jonathan Crane (1991), and James E. Rauch (1992).
} 
were raised, and these neighborhood characteristics influence intergenerational mobility: In other words, the ethnic capital model provides an alternative way of capturing neighborhood effects. Ethnic capital, however, plays an additional role in intergenerational mobility. Even among persons who grow up in the same neighborhood, ethnic capital matters when children are frequently exposed to other persons who share the same ethnic background.

\section{Ethnicity and Neighborhoods}

Because little is known about the residential clustering of many of the ethnic groups used in the empirical analysis below, it is useful to first document the link between ethnicity and residential segregation. ${ }^{3}$ The descriptive analysis is based initially on data drawn from the $1 / 100$ Neighborhood file of the 1970 U.S. Census (15 percent questionnaire). These data not only contain the individual-level demographic variables typically available in Census files, but also group individuals into one of 42,950 "neighborhoods." Neighborhoods are contiguous, relatively compact, roughly the size of a Census tract, and have an average population of 4,000 persons (U.S. Bureau of the Census, 1973). Although the specific geographic location of a neighborhood cannot be determined (other than its location in one of the nine Census regions), the data file reports a number of demographic characteristics describing the neighborhood (such as the fraction of persons who are either first- or second-generation Americans, and the fraction of persons who are college graduates).

\footnotetext{
${ }^{3} \mathrm{~A}$ large literature documents the ertent of residential segregation among blacks and Hispanics; sec Frank D. Bcan and Marta Tienda (1987), Nancy A. Denton and Douglas S. Masscy (1989). Mark Alan Hughes and Janice Fanning Madden (1991), and Scott McKinney and Ann B. Schnare (1989).
} 
I restrict the analysis to persons aged 18-64. I begin by documenting the residential segregation of immigrants and second-generation Americans, and the extent to which residential segregation changes across generations. A person is an immigrant if he or she was bom outside the United States (or its possessions), and is a second-generation American if either parent was bom outside the United States. All other persons are grouped and labeled "third-generation" Americans, although this sample obviously includes higher-order generations. The 1970 Census does not provide any information on the ethnic ancestry of persons in the "third" generation.

As noted above, the neighborhood file reports the proportion of the population in each neighborhood that is either first- or second-generation. This statistic was calculated by the Bureau of the Census using all available observations in the neighborhood (i.e., the 15 percent sample of respondents who filled out the relevant questionnaire). I use these data to estimate the fraction of persons in the neighborhood who are either first- or second-generation for the average person in a number of demographic groups.

Table I summarizes the extent of residential segregation. The first row reports that the average immigrant resided in a neighborhood where 32.7 percent of the population was either first- or second-generation. This pattern of residential location differs significantly from what one would expect if immigrants were randomly allocated across neighborhoods. The 1970 Census indicates that only 16.6 percent of the population was first- or second-generation.

Because the aggregate characteristics reported in the neighborhood file do not include the proportion of the neighborhood's population that is foreign-born, I calculate this statistic by combining the birthplace data reported in each individual's record with the aggregate 
neighborhood characteristics provided by the Census Bureau. ${ }^{4}$ The typical immigrant lives in a neighborhood that is 15.3 percent immigrant, even though only 4.8 percent of the population was foreign-bom.

Residential segregation persists into the second generation. As the second row of Table 1 shows, the average second-generation American resides in a neighborhood that is 28.2 percent first- or second-generation.

The 1970 Census does not provide any information on ancestry past the second generation. As a result, I cannot determine how the pattern of residential segregation changes beyond the second generation for most groups. Intergenerational changes in residential segregation, however, can be documented for the subpopulation of Hispanics, the vast majority of whom are foreign-bom or have parents or grandparents who are foreign-born.s Table 1 indicates that there is very little movement of Hispanics out of Hispanic neighborhoods even in the third generation. The average Hispanic immigrant lives in a neighborhood that is 35 percent Hispanic; the second-generation Hispanic lives in one that is 33 percent Hispanic; and the typical thirdgeneration Hispanic lives in one that is 29 percent Hispanic. The fraction of Hispanics in the population is only 4.4 percent. The clustering of Hispanics into Hispanic neighborhoods, therefore, is prevalent and persistent. ${ }^{6}$

In particular, I take the Census Bureau estimale of the proportion of persons in the neighborhood who are first- or second-generation to be the population proportion. I then multiply this number by the sample estimate of the proportion of the first- and second-generation persons in the neighborhood who are foreign-bom.

'Calculations from ihe Gcneral Social Surveys indicalc that over 90 percent of persons who classify themselves as Hispanic are foreign-bom, have parents who are foreign-bom, or have grandparents who are foreign-bom.

${ }^{6}$ Although the residential scgregation found among thesc ethnic groups is substantial, it is nol nearly as striking as that found among blacks. Table 1 reports that the average black lives in a neighborhood that is 54.7 percent black. 
In addition to the clustering of first- and second-generation persons into certain neighborhoods, there is substantial segregation by ethnic group. To document the differences across national origin groups, I focus on the 39 largest groups in the data. These 39 groups include 83.7 percent of all first-generation Americans, and over 95 percent of all secondgeneration Americans. The national origin of immigrants is, of course, determined by their country of birth. The national origin of a second-generation person is determined by the father's birthplace (unless only the mother was foreign-born, in which case it is determined by the mother's birthplace). Table 2 lists the 39 national origin groups used in the analysis.

I first calculated the proportion of the population who are either first- or secondgeneration and who have a particular ethric ancestry. This number is reported in the first column of the table, and represents the probability that a first- or second-generation person from that group will be found in a particular neighborhood if the ethnic group was distributed randomly across neighborhoods. Most of the groups make up relatively small fractions of the population: only 0.8 percent of the population, for instance, is first- or second-generation Irish.

Table 2 reveals that immigrants and their children, regardless of national origin, cluster in neighborhoods that have large numbers of first- or second-generation Americans. The typical second-generation person of English ancestry resides in a neighborhood that is 23.5 percent firstor second-generation; the respective statistic for Irish persons is 31.3 percent. for Italians 32.0 percent, and for Mexicans 27.8 percent. There is little evidence, therefore, that only economically disadvantaged groups are crowded into ethric neighborhoods.

To document how type-j ethnics cluster in specific neighborhoods. I calculate the fraction of the neighborhood's population that has the same ethnicity as the average type-j person. The Census Bureau does not report the fraction of the population in each neighborhood that belongs 
to each of the groups. Hence I calculated this statistic from within the $1 / 100$ sample. Because the family members of a type-j ethnic are likely to be type-j ethnics, and because the $1 / 100$ Census file is a random sample of households, the stratified sampling scheme introduces an upward bias in the calculation of the fraction of the neighborhood's population that is type $j$. I choose a conservative index of within-group residential segregation, and calculate (for each person in the data) the proportion of persons in the neighborhood who reside outside the household unit and who are type-j ethnics. ${ }^{7}$ Table 2 reports the average of this statistic for each of the groups. In view of the relatively small sample size available for each neighborhood (the mean and median number of observations in a neighborhood is 26 , and the interquartile range is 9 , from 21 to 30 ), some caution is required in the interpretation of the data.

The probability that type-j ethnics live near other type-j ethnics is much higher than one would expect if type-j ethnics were randomly distributed across neighborhoods. Among secondgeneration workers, the typical person of Irish ancestry lives in a neighborhood that is 3.3 percent Irish, although first- and second-generation Irish make up only 0.8 percent of the population; the typical Italian lives in a neighborhood that is $\mathbf{1 2 . 1}$ percent Italian, although Italians make up only 2.8 percent of the population; and the typical Mexican lives in a neighborhood that is 18.1 percent Mexican, although Mexicans make up only 1.3 percent of the population. Among the 39 national origin groups, the typical immigrant lives in a neighborhood in which 8.3 percent of the population shares the same ethnic background, and the typical second-generation person lives in a neighborhood in which 6.6 percent of the population shares the same background.

\footnotetext{
${ }^{7}$ This methodology does not entirely solve the problem because extended family members are also likely to be type-j cthnics and to live in the same neighborhood (but as part of a different household unit).
} 
I conclude the descriptive analysis of the Census data by documenting that ethnic residential segregation exists across a number of demographic and skill groups. Table 3 shows that there is little difference in ethnic residential segregation across age groups. The typical second-generation person aged $18-34$ resides in a neighborhood that is 27.4 percent first- or second-generation, while the respective statistic for an older person is 28.5 percent. In addition, the differences in residential segregation across education groups are often small. The typical high school dropout in the second generation lives in a neighborhood that is 28.7 percent first- or second-generation, while the respective statistic for the typical college graduate is 27.8 percent. Finally, the data indicate that internal migration decisions among first- and second-generation - Americans do not seem to alter the ethnic composition of their residential environment. Secondgeneration persons who have lived in the same house for over 10 years live in a neighborhood that is 29.4 percent first- or second-generation, while the respective statistic for persons who have lived in the house fewer than 3 years is 26.3 percent.

The NLSY reveals even stronger patterns of residential segregation. The analysis uses a version of the NLSY that identifies the subset of persons who resided in the same zip code in 1979 , at the time the survey of young persons (aged 14-22) began. Hence it is possible to determine if NLSY respondents live near other NLSY respondents who share the same ethric background. ${ }^{\mathrm{s}}$

\footnotetext{
${ }^{8}$ The numbering system used to identify zip codes in the NLSY file differs from that uscd by the Postal Service. Although the data indicate which subset of NLSY respondents live in the same postal area, it is impossible to locate the zip code within a particular metropolitan area. Because the zip code refers to the 1979 residence, many of the respondents sere still living in the parental houschold,. As a result, the residential segregation measures in the NLSY tend to reflect the ethnic environment in which the respondents were raised.
} 
Ethricity is determined from the response to the question: "What is your origin or descent?" Although most persons in the NLSY gave only one response to the question, about one third of the respondents gave multiple answers. In these cases, I used the main ethnic background (as identified by the respondent) to classify people into ethnic categories.

For each person in the data, I calculated the probability that other NLSY respondents in the zip code had the same ethric background. The NLSY, however, surveyed other persons in the family unit who were in the "correct" age range (i.e., 14-22 in 1979). As a result, there are a large number of siblings in the data: 27 percent of the respondents have one sibling, and an additional 19 percent have at least two siblings. To avoid the bias introduced by this sampling scheme, I calculated the residential segregation measures on the sample of non-related persons who reside outside the household unit. 9 Moreover, because the NLSY oversampled blacks and other minorities, I used the sampling weights in the calculations.

The segregation indices are reported in Table 4 for the 25 ethnic groups identifiable in the NLSY. ${ }^{10}$ There is strong evidence of residential segregation. The average black lived in a neighborhood that was 63.4 percent black, while the average Mexican lived in a neighborhood that was 50.3 percent Mexican. Overall, the typical NLSY respondent lived in a neighborhood where 30.4 percent of other non-related respondents shared a common ethnic background ${ }^{1}$

\footnotetext{
'To reduce costs, the NLSY also sampled households which resided geographically close to each other. This sampling strategy suggests that the measures of residential segregation calculated in these data probably overstate the true extent of segregation.
}

${ }^{10}$ Of the 12,686 observations in the 1979 wave of the NLSY, I deleted 2 persons because they had invalid zip codes, and 939 persons because they had invalid ethnic classifications.

\footnotetext{
"As with the Census data, the NLSY residential segregation measures should be interpreted with caution. There are fewer than 100 observations for 11 of the 25 ethnic groups.
} 
Note that this statistic is much larger than the respective statistic in the Census data, where only 7 to 8 percent of the neighborhood's population belonged to the same group. The Census results, however, underestimate the extent of residential segregation because all third-generation workers are classified as non-ethnics (because no information is provided on the ethnic background of third-generation persons). As a result, even though the typical immigrant in the Census lives in a neighborhood where 8.3 percent of the population is composed of first- or second-generation persons who belong to the same ethnic group, a much larger fraction of the neighborhood's population might be composed of third-generation workers who also belong to the same ethnic group. The NLSY avoids this problem because all persons in the data (regardless of their generation) report their ancestry.

\section{Econometric Framework}

My objective is to determine the relationship between ethnic externalities and neighborhood effects in the intergenerational transmission process. The econometric model underlying the analysis is given by:

$$
y_{i j}=\beta_{1} x_{i j}+\beta_{2} \bar{x}_{j}+\varepsilon_{i j} \text {, }
$$

where $y_{i j}$ measures the skills (such as educational attainment or the log wage) of person $i$ in ethnic group $j ; x_{i j}$ gives the skills of his father; and $\bar{x}_{j}$ gives the average skills of the ethnic group in the father's generation (which I call ethnic capital). Note that $\bar{x}_{j}$ takes on the same value for all persons in group $j$. All variables are measured in deviations from the mean. 
Equation (1) can be derived from a model where utility-maximizing parents invest in their children, and where ethnicity has an external effect on the production of children's skills (Borjas, 1992). As a result of the ethnic spillover, the human capital of children depends not only on parental inputs (as measured by the exogenous human capital of the parents), but also on the external effect of ethnicity, as summarized by the average skills of the ethnic group.

The spillover effects underlying the ethnic capital model have much in common with the human capital externalities that are at the heart of the recent literature on economic growth (Lucas, 1988; Paul M. Romer, 1986), as well as with the notions of social capital and neighborhood effects that are stressed routinely in the sociology literature (James S. Coleman, 1988, 1990; Wilson, 1987). If the ethnic externality is sufficiently strong, skill differentials observed among ethnic groups can persist for many generations and may never disappear. Note that the expected skills of the son of the average father in ethnic group $j$ are given by:

$$
E\left(y_{i j}\right)=\left(\beta_{1}+\beta_{2}\right) \bar{x}_{j}
$$

The sum $\beta_{1}+\beta_{2}$, therefore, determines if the mean skills of ethnic groups converge across generations; hence $\beta_{1}+\beta_{2}$ is an inverse measure of the rate of "mean convergence."12 If the sum of coefficients is less than one, ethnic differences converge over time; if it is greater than one, ethnic differences diverge across generations.

\footnotetext{
${ }_{12}$ Rober J. Barro and Xavier Sala-i-Martin (1992) provide a discussion of alternalive concep1s of convergence in the context of growth models.
} 
As we have seen, ethnic groups cluster in particular neighborhoods. This clustering suggests that part of the ethnic capital effect in equation (1) may be capturing the influence (if there is one) of the neighborhood's socioeconomic background on intergenerational mobility. Suppose, for example, that ethnic groups are completely segregated so that there is one ethnic group per neighborhood. The ethnic capital variable $\vec{x}_{j}$ would then also represent the mean skills of the neighborhood, and the coefficient $\beta_{2}$ in (1) would capture the total impact of the ethnic spillover and of the neighborhood's socioeconomic background. The coefficient of ethnic capital would be significant even if ethnicity did not have a direct impact on intergenerational mobility, but neighborhood characteristics mattered.

The data do not exhibit this extreme type of segregation. Ethnic groups, however, are likely to cluster by skill level, so that unskilled ethnic groups live together in low-income neighborhoods and skilled ethnic groups live in high-income neighborhoods. The ethnic capital variable would again be correlated with the skill level of the neighborhood, and the ethnic capital coefficient could be capturing neighborhood effects (i.e., the impact of the neighborhood's overall socioeconomic background), rather than the direct effect of ethnicity. In effect, the ethnic capital model "works" because ethnic capital proxies for the relevant neighborhood characteristics which influence the intergenerational transmission process. If ethnicity did not have a direct impact on intergenerational mobility, controlling for the relevant neighborhood characteristics (such as mean income and education) would drive the ethnic capital coefficient down to zero.

Ethnic capital might still matter, above and beyond neighborhood effects, if intra-group contacts within a neighborhood are more frequent or are more influential than inter-group 
contacts. ${ }^{13}$ Children who belong to ethric group $j$ are then exposed to a different set of values, social contacts, and economic opportunities than children who belong to other ethnic groups but who grow up in the same neighborhood. In effect, the aggregate socioeconomic characteristics of the neighborhood are not a sufficient statistic summarizing the environment facing type-j persons. As a result, ethnic capital influences the intergenerational mobility process even after controlling for neighborhood effects. Ethnicity per se has an impact on intergenerational mobility.

The empirical work presented in this paper decomposes the impact of the ethnic capital coefficient into neighborhood effects (the extent to which the ethnic capital variable proxies for neighborhood characteristics which influence all persons who reside in the same neighborhood, regardless of ethnic background) and into an ethnic effect. A simple way of determining the extent to which the impact of ethnic capital (i.e., the coefficient $\beta_{2}$ ) operates through neighborhood effects is to expand the model in (1) to include a vector of neighborhood fixed effects:

$$
y_{i j}=\delta_{1} x_{i j}+\delta_{2} \bar{x}_{i}+\sum_{k} \theta_{k} D_{i j}^{k}+\varepsilon_{i j}^{\prime}
$$

where $D_{i j}^{k}$ is a dummy variable set to unity if person $i$ in ethnic group $j$ resides in neighborhood $k$.

The parameter vector $\left(\theta_{1}, \cdots, \theta_{k}\right)$ gives the neighborhood fixed effects, which are assumed to be

\footnotetext{
${ }^{13}$ Richard D. Alba's (1990) study of social contacts among U.S.-bom whitc ethnics indicatcs that half of all non-related childhood friends belong to the samc ethnic group. Harn J. Holzer (1988) has shown that friends are a key source of information about job opportunities, so that intra-group referrals play a major role in the job search process and might explain the concentration of some clhnic groups in narrowly-defincd occupations.
} 
exogenous. ${ }^{14}$ The coefficients $\delta_{1}$ and $\delta_{2}$ measure the within-neighborhood impact of parental skills and of ethnic capital. As long as neighborhoods matter in the transmission of skills, the "net" rate of mean-convergence (i.e., net of neighborhood effects) implied by the fixed-effects model, $\delta_{1}+\delta_{2}$, is conceptually different from the "gross" rate implied by equation (1), $\beta_{1}+\beta_{2}$. Equations (1) and (3) can be estimated directly in the NLSY data discussed above. It is unusual, however, to come across data that contain all the requisite information: ethnicity, the skills of two generations of workers, and neighborhood of residence. Nevertheless, a relatively complete analysis of the relationship between ethnic capital and neighborhood effects can be conducted even if the data do not provide any information on parental background (as is the case with the 1970 Census neighborhood file). In particular, suppose mean parental skills in the group, $\bar{x}_{j}$, are observed even if parental skills are not (the source of the data on $\bar{x}_{j}$ will be discussed below). The individual-level data available for second-generation workers in the 1970 Census can then be used to estimate the regression models:

$$
\begin{aligned}
& y_{i j}=\beta \bar{x}_{j}+\omega_{i j}, \\
& y_{i j}=\delta \bar{x}_{j}+\sum_{k} \theta_{k} D_{i j}^{k}+\omega_{i j}^{\prime} .
\end{aligned}
$$

Because equations (4) and (5) regress individual-level data on an aggregate measure of ethnic skills, I call this type of model a "semi-aggregate" regression. It is easy to show that:

\footnotetext{
${ }^{14}$ It would be interesting to analyze how parents choose the type and intensity of "ethnicity" that they wish 10 expose to their children. William N. Evans, Wallace E. Oales, and Robert M. Schwab (1992) show that endogenizing the "peer group" effects greatly weakens the relationship belwcen outcomes and neighborhood characteristics.
} 
Proposition 1. $E(\hat{\beta})=\beta_{1}+\beta_{2}$.

Data on parental skills, therefore, are not required to estimate the gross rate of mean convergence. Because the mean skills of the ethnic group instrument for parental skills, the omitted variable bias introduced by leaving out parental skills is simply the "recovery" of the coefficient $\beta_{1}$. It would now be useful to determine if $E(\hat{\delta})=\delta_{1}+\delta_{2}$, so that the net rate of mean convergence can also be estimated without information on parental skills. I proceed to show that this is indeed the case in an important special case, and that the difference between the gross and net rates of mean convergence is attributable solely to the change in the ethnic capital coefficient.

Consider first how the coefficients of parental and ethnic capital in equation (1) change when neighborhood fixed effects are introduced into the model. The probability limits of the estimated coefficients in (1) when the true model is given by (3) are:

(6) $\operatorname{plim} \hat{\beta}_{1}=\delta_{1}+\frac{\operatorname{Var}\left(x_{i j}\right)}{\Delta}\left\{\sum_{\ell>t} \sum_{k} p_{\ell}\left(\theta_{\ell}-\theta_{k}\right)\left[\left(E\left(x_{i j} \mid \ell\right)-E\left(\bar{x}_{j} \mid \ell\right)\right)-\left(E\left(x_{i j} \mid k\right)-E\left(\bar{x}_{j} \mid k\right)\right)\right]\right\}$,

(7) $\operatorname{plim} \hat{\beta}_{2}=\delta_{2}+\frac{\operatorname{Var}\left(x_{i j}\right)}{\Delta}\left\{\sum \sum_{\ell>k} p_{k} p_{\ell}\left(\theta_{\ell}-\theta_{k}\right)\left[\left(E\left(\bar{x}_{j} \mid \ell\right)-E\left(\bar{x}_{j} \mid k\right)\right)\right]\right\}$

$$
-\frac{\operatorname{Var}\left(\bar{x}_{j}\right)}{\Delta}\left\{\sum_{\ell>k} p_{k} p_{\ell}\left(\theta_{\ell}-\theta_{k}\right)\left[\left(E\left(x_{i j} \mid \ell\right)-E\left(x_{i j} \mid k\right)\right)\right]\right\}
$$

where $\Delta=\operatorname{Var}\left(x_{i j}\right) \operatorname{Var}\left(\bar{x}_{j}\right)-\operatorname{Var}\left(\bar{x}_{j}\right)^{2} ; p_{k}$ is the fraction of the population that lives in neighborhood $k, E\left(x_{i j} \mid k\right)$ is the mean value of skills among parents who live in neighborhood $k$, 
where the expectation is evaluated over all $i$ and $j$, and $E\left(\bar{x}_{j} \mid k\right)$ is the mean value of the ethnic capital variable among all persons who live in neighborhood $k$, where the expectation is again evaluated over all $i$ and $j$.

In general, the introduction of neighborhood effects affects the coefficients of both parental skills and ethnic capital. Suppose, however, that type- $\tau$ ethnics residing in region $k$ are a random sample of the population of type- $\tau$ ethnics, so that the skill distribution of type- $\tau$ ethnics in region $k$ is the same as their skill distribution in the population. This assumption implies:

$$
E\left(x_{i r} \mid k\right)=\bar{x}_{\tau},
$$

where the expectation in the left-hand-side is taken over all $i$ in group $\tau$ in neighborhood $k$, while the right-hand-side simply gives the level of ethnic capital for group $\tau$. I refer to (8) as the "skillinvariance" assumption. Equation (8) implies $E\left(x_{i j} \mid k\right)=E\left(\bar{x}_{j} \mid k\right), \forall k$, so that the bracketed term in (6) vanishes. It is useful to summarize this result as:

Proposition 2. If the distribution of type-j ethnics across neighborhoods is skill-invariant, $\operatorname{plim} \hat{\beta}_{1}=\delta_{1}$, and the coefficient of parental skills is unaffected by the introduction of neighborhood fixed effects.

Note that the skill-invariant geographic assignment of type $j$ workers is distinct from and weaker than assuming that type- $j$ ethnics are distributed randomly across neighborhoods. 
The skill invariance assumption is also useful in determining the relationship between the estimator $\hat{\delta}$ (from equation (5)) and the net rate of mean convergence. This relationship is summarized by:

Proposition 3. If the distribution of type-j ethnics across neighborhoods is skill-invariant, then $\operatorname{plim} \hat{\delta}=\delta_{1}+\delta_{2}$

As before, it is unnecessary to have information on parental skills in order to estimate the rate of mean convergence (net of neighborhood effects).

The results can now be used to determine why the two rates of mean convergence estimable in Census data might differ. Because the coefficient of parental skills is unaffected by the introduction of neighborhood fixed effects, the difference between the "gross" and "net" rates of mean convergence is attributable entirely to the change in the coefficient of the ethnic capital variable (assuming the skill invariance assumption holds). Therefore, the inclusion of neighborhood fixed effects into semi-aggregate regressions can be used to assess the relationship between ethnic capital and geography. I summarize this result as:

Proposition 4. Suppose the distribution of type-j ethnics is skill-invariant. The difference in the estimated rates of mean convergence $\hat{\beta}$ and $\hat{\delta}$ gives the impact of neighborhood effects on the ethnic capital coefficient. 
Because of the practical importance of these results, it is worth stressing that the skill invariance assumption is unlikely to hold strictly in the data. The analysis of the Census data presented below uses two alternative measures of skills (educational attainment and log wages) to estimate the rate of mean convergence. Even if there were no skill differentials among type- $j$ workers residing in different neighborhoods, the restriction in (8) would be violated if there exist neighborhood wage differentials which are independent of skills. These differentials imply that the mean wage of type-j parents in a particular neighborhood differs from the measure of ethnic capital for group $j$. Therefore, the analysis must control for regional wage differentials prior to applying the results presented above. The construction of an index of regional wage differentials at the neighborhood level is discussed below.

A more difficult problem with the skill-invariance assumption is simply that the skill distribution of type-j ethnics probably does differ across neighborhoods. ${ }^{\text {is }}$ I will show below, however, that the restriction implied by skill invariance is not grossly inconsistent with the geographic sorting of type-j ethnics.

Finally, the discussion has assumed that the ethnic capital effect is constant across neighborhoods and persons. This need not be the case. In fact, the ethnic capital model implies that the spillover effects of ethnicity should be larger for persons who are more frequently

\footnotetext{
15It is easy to determine how the coefficients of parental skills and ethnic capital change when neighborhood effects are introduced into the model and the skill invariance assumption does not hold. Suppose that highly-skilled type-j workers move inlo wealthy neighborhoods, and unskilled type-j workers move inlo poor neighborhoods. This implies that $E\left(x_{i j} \mid \ell\right)>E\left(\bar{x}_{j} \mid \ell\right)$ in wealthy neighborhoods ( () and that $E\left(x_{y} \mid k\right)<E\left(\bar{x}_{j} \mid k\right)$ in low-income neighborhoods $(k)$. Il follows from equation (6) that $E\left(\hat{\beta}_{1}\right)=\delta_{1}+\varphi$, where $\phi>0$. Thus the nonrandom soning of skilled workers into "good" neighborhoods magnifies the impact of the parental contribution 10 the children's skills. As a result, the inclusion of neighborhood effects will reduce the coefficient of parental skills in the intergenerational transmission equation. It is also easy to show that this type of nonrandom sorting leads 10 a smaller ethnic capital coefficient in models which omit the neighborhood fixed effects.
} 
exposed to an ethnic environment. Put differently, the ethnic capital effect should be larger for those children who grow up in neighborhoods where many of the residents share the same ethnic background. The empirical analysis presented below investigates the extent to which the ethnic capital effect depends on the ethnic composition of the neighborhood.

\section{Results}

I initially use the sample of second-generation workers in the 1970 Census file to analyze the relationship between ethnic externalities and neighborhood effects. I restrict the analysis to second-generation men aged 18-64, who worked in the civilian sector in the year prior to the Census, who were not enrolled in school, and who were not self-employed. As before, the ethnic group of the second-generation worker is defined in terms of the father's birthplace (unless only the mother was foreign-born, in which case it is defined in terms of the mother's birthplace). I use two alternative measures of the worker's skills, educational attainment and log wage rates.

Because Census data do not directly link the skills of second-generation Americans with the skills of their immigrant parents, I use the 1/100 Public Use Sample of the 1940 Census to estimate the mean skills of the national origin group in the parent's generation. It is likely that (adult) second-generation persons enumerated in the 1970 Census are the children of the immigrants who arrived in the period prior to 1940.16

\footnotetext{
${ }^{16}$ Borjas (1993) discusses the methodolog: of intercensal comparisons that underlie the empirical analysis using the Census data. The intercensal linkage between parents and children can be improved by focusing on workers in specific age groups. For example, the children of immigrants aged $25-44$ in 1940 are likely to be relatively young in 1970 . I experimented with a number of altemative age breakdowns and obtained similar results.
} 
Table 5 reports the average educational attainment and log wages for the 36 ethnic groups that can be identified in both the 1940 and 1970 Censuses with sufficiently large numbers of observations. These 36 ethnic groups make up 97.4 percent of working immigrant men in 1940 , and 95.5 percent of the second-generation working men in 1970. There is substantial dispersion in skills and wages across national origin groups and there is a strong positive correlation between the skills of the immigrant group in 1940 and the skills of the corresponding second-generation group in 1970.

To calculate the variable measuring mean skills in the parent's generation (i.e., the empirical measure of ethnic capital), I pool the sample of immigrant and native men in the 1940 Census (for a total of 231,606 observations), and estimate the regression model:

$$
x_{i j}=Z_{i j} \alpha+\sum_{j} \gamma_{j} G_{i j}+\varepsilon_{i j}
$$

where $x_{i j}$ gives the skills of person $i$ in national origin group $j ; Z_{i j}$ is a vector of socioeconomic characteristics including age, age squared, and region of residence; and $G_{\text {if }}$ is a dummy variable set to unity if person $i$ belongs to group $j$ (natives are the omitted group). The regression is estimated separately using educational attainment and the log wage rate as dependent variables. The parameter vector $\left(\gamma_{1}, \cdots, \gamma_{j}\right)$ gives the empirical measure of ethnic capital for the $J$ groups.

Table 6 reports the estimated rates of mean convergence. Equations (4) and (5) give the basic specification of the model, except that the regressions also control for the second-generation worker's age and age squared. The regressions use a random-effects estimator which allows for 
an ethnic group-specific component in the error term. ${ }^{17}$ Consider initially the middle panel reporting the transmission coefficients obtained in the log wage regression model. Column 1 indicates that the rate of mean convergence (or $\beta_{1}+\beta_{2}$ in terms of the model in the previous section) is $\mathbf{0 . 4 5}$, in line with the results of earlier work (Borjas, 1992, 1993).

The next column controls for the bias introduced by regional wage differentials. As noted above, the skill-invariance assumption is violated if some ethnic groups have relatively high wage levels simply because they live in high-wage areas. To control for regional wage variation, I estimated the following regression in the sample of third generation workers in the 1970 neighborhood file:

$$
w_{i}=X_{i} \alpha+\sum_{k} \psi_{k} D_{i}^{k}+\varepsilon_{i}
$$

where $w_{l}$ gives the log wage of person $i ; X$ is a vector of standardizing variables (including educational attainment, age, age squared, marital status, and dummy variables indicating if the person is black or Hispanic); and $D_{i}^{k}$ is a dummy variable indicating if person $i$ resides in neighborhood $k$. The vector $\left(\psi_{1}, \cdots, \psi_{k}\right)$ gives the skill-adjusted neighborhood wage level. This wage level is included as an additional regressor in the intergenerational earnings equations, and the resulting transmission coefficient is reported in column 2 of Table $6 .{ }^{18}$ The transmission coefficient falls to 0.40 (a drop of about 0.05 units).

\footnotetext{
${ }^{17}$ In particular, the residual $\varepsilon_{j j}=v_{j}+u_{i j}$, where $v_{j}$ is the group component. It is well known that ignoring the group component in the error term seriously underestimates the slandard error of the ethnic capital coefficient.

${ }^{18}$ The coefficient of the neighborhood wage level was typically in the 0.4 to 0.5 range.
} 
Column 3 of the table adds the vector of neighborhood fixed effects into the regression. ${ }^{19}$

Controlling for the neighborhood fixed effects reduces the estimated transmission parameter

substantially, to about 0.2 . Assuming that the skill-invariance assumption holds, the transmission coefficient changes because the estimate in column 3 "nets out" the relationship between the ethnic externality and neighborhood effects (but leaves unchanged the impact of parental skills).

It is interesting to note that the resulting coefficient of 0.2 is roughly the same as the coefficient of parental capital in my earlier work (Borjas, 1992). It seems as if neighborhood effects account for most (if not all) of the ethnic influence in the intergenerational transmission process. Ethnic capital seems to be a very good proxy for the relevant characteristics of the neighborhood's economic and social environment which influence the intergenerational transmission process and which are common to all persons living in the same neighborhood, regardless of ethnicity. ${ }^{20}$

The last three columns of Table 6 use the 1/100 County Group file of the 1970 Public Use Sample (15 percent questionnaire) to estimate an identical model in a sample of second-generation

${ }^{19}$ There are 53,703 observations in the sample of second-generation working men and 23,415 neighborhoods. There are 9,522 neighborhoods with only one observation; 5,895 neighborhoods with Iwo; 3,616 neighborhoods with three; 2,162 neighborhoods with 4; and 1,161 neighborhoods with 5 . The remaining 5 percent of the neighborhoods have between 6 and 12 observations. Despite the fact that a sizable number of neighborhoods have only 1 observation, the estimated rate of mean convergence is consistent. I use a two-stage procedure to estimate the random effects model which includes the vector of neighborhood fixed effects. The first stage regression includes age, age squared, and a vector of ethnic fixed effects. This regression is estimated on a data set where all variables are differenced form the respective neighborhood means. This procedure is numerically equivalent to introducing the neighborhood fixed effects. The second stage then uses a GLS estimator to estimate the relationship between the coefficients of the first-stage ethnic dummy variables and the ethnic capital variable.

${ }^{20}$ The discussion assumes that the neighborhood of current residence is the same as the neighborhood where the individual was raised. Because of the misdefinition of the neighborhood. the results confound the ethnic externalities that influenced the human capital accumulation process with externalities that arise from living in an ethnic neighborhood at the present time. This problem, however, does not seem to be very important. The results are very similar for two alternative skill variables, log wages and educational attainment (which presumably was completed at an early age). Moreover, the transmission coefficients are roughly the same regardless of how long the person has lived in his current residence. The estimated transmission parameter is 0.43 for persons who moved to the house prior 101960 , and is 0.46 for persons who moved to the house after 1967. 
workers defined exactly as in columns 1-3. This Census file reports the metropolitan area (instead of the neighborhood) of current residence. Persons who live outside metropolitan areas are grouped into economically similar "county groups." A total of 408 metropolitan areas and county groups are identified in the data.

Not surprisingly, the transmission coefficient reported in column $S$ is almost identical to the respective statistic in column 1 . To control for regional wage variation, I estimated a regression in the sample of third-generation workers similar to (10) with county group dummies instead of neighborhood dummies. The skill-adjusted county wage level was then introduced as an additional regressor in the model. This reduced the coefficient to about 0.37 , which is roughly the same as the analogous coefficient in column 2 .

The coefficient in the last column of Table 6 , however, differs drastically from the respective coefficient in column 3 . Controlling for county fixed effects barely affects the estimated transmission coefficient; it remains at about 0.4 . Put differently, the ethric capital variable and the vector of county fixed effects are uncorrelated. There is no evidence, therefore, that ethnic capital has anything to do with geography at the county level. At the neighborhood level, however, geography is intimately linked to the ethnic capital effect.21

The top panel of Table 6 reports the transmission coefficients obtained from regressions which use the worker's educational attainment as the dependent variable. The results are virtually identical to those obtained in the log wage regressions. Including the neighborhood fixed effects

${ }^{21}$ A regression of education (or log wages) on a vector of country group dummics has an R-squared of about 0.09 , so that 91 percent of the variance in educalion and log wages is attribulable to within-county variation. In contrast, only about 45 percent of the variance in these variables is altributable to withinneighborhood variation. 
reduces the transmission coefficient from 0.36 to 0.17 , while adding in the county dummies barely changes the estimated parameter (it declines to 0.33). ${ }^{22}$

Finally, the bottom panel of Table 6 reports the transmission coefficients obtained in a log wage regression which also includes the educational attainment of the second-generation worker as a regressor. Although the transmission rates are much smaller (because the transmission that occurs through educational attainment is netted out), adding neighborhood fixed effects changes the estimated coefficients in exactly the same way an in the top two panels of the table.

In sum, the analysis reveals a link between ethnic capital and neighborhood effects, but it provides no information about which set of neighborhood characteristics are being proxied by the ethnic capital variable. Column 4 of Table 6 shows that the neighborhood fixed effects can be summarized in terms of a small number of neighborhood characteristics. The neighborhood characteristics included in the regression are: the percent of the neighborhood's population that has at least a high school diploma; the percent that has at least a college diploma; the labor force participation rates of men and women; the unemployment rate; the percent of workers employed in professional occupations; the percent of families below the poverty level; and the percent of families with at least $\$ 15,000$ in household income. All of these neighborhood characteristics were calculated by the Census Bureau (and are included in the Public Use Sample).

The inclusion of these aggregate neighborhood characteristics reduces the transmission coefficient from 0.36 to 0.27 in the education regressions, and from 0.4 to 0.25 in the log wage regressions. In other words, a small vector of variables that are common to all persons living in 
the neighborhood, regardless of ethnic background, can explain over half of the drop in the ethnic capital coefficient. ${ }^{23}$

It seems, therefore, that a large part of the impact of ethnic capital is simply disguising for neighborhood effects which have nothing to do with ethnicity. This interpretation of the results, of course, depends on the validity of the skill-invariance assumption. As shown in Section II, when the distribution of persons across neighborhoods is skill-invariant, including neighborhood effects in semi-aggregate regressions reduces the estimated rate of mean convergence solely because the ethnic capital coefficient is "standing in" for neighborhood effects.

Parental skills are not observed in the Census data, so that it is not possible to assess directly the validity of the skill-invariance assumption. I can test, however, if the geographic distribution of second-generation workers rejects the skill-invariance assumption. Consider the following regression model:

$$
y_{i j k}=\gamma_{0} G+\gamma_{1}(G \times D)+\varepsilon_{i j k}
$$

where $y_{i j k}$ gives the skills of second-generation worker $i$ in group $j$ in neighborhood $k, G$ gives a vector of dummy variables indicating the worker's ethnic group; and $D$ gives a vector of dummy variables indicating the worker's neighborhood. The skill invariance assumption states that the mean skills of a worker in ethric group $j$ are independent of the neighborhood of residence, so that the coefficient vector $\gamma_{1}$ is zero.

\footnotetext{
${ }^{23}$ Although I do not report or discuss the estimated coefficients of the neighborhood characteristics. it would be Interesting to study how (and why) these various characieristics infuence the intergenerational
transmission process.
} 
I calculated the analysis of variance decomposition implied by (11) using both the educational attainment and log wage of workers in the second generation. ${ }^{24}$ To net out the impact of regional wage differentials on the analysis, the worker's log wage is deflated by the skill-adjusted neighborhood wage level defined earlier. Despite the very large samples used in the analysis, testing the hypothesis that the coefficient vector $\gamma_{1}$ differs from zero yields F-statistics which are barely above the critical value of $\mathrm{l}$; the F-statistic in the educational attainment regression was 1.21 , and the F-statistic in the log wage regression was 1.18 . In contrast, the Fstatistic testing the significance of the group effect (i.e., whether the coefficient vector $\gamma_{0}$ was zero) was 17.2 in the educational attainment regressions and 95.9 in the log wage regressions, substantially above the critical value of $1.4 .^{2 \mathrm{~s}}$

I now use the NLSY (where parental skills are observed and where it is unnecessary to maintain the skill invariance assumption) to confirm that there is a very strong link between neighborhood effects and the ethnic capital coefficient. The analysis uses the 1990 wave of the NLSY, by which time the respondents were aged 25-33 and only about 5 percent were still enrolled in school. Equations (1) and (3) give the basic specifications of the models. The regressions also control for age, gender, whether the person is a first- or second-generation American, and whether the person was enrolled in school in 1990.

${ }^{24}$ The test excludes the 9,522 neighborhoods that have only 1 second-generation working man.

${ }^{25} \mathrm{~A}$ related way of assessing the importance of the skill-invariance assumption uses the conccpt of the intracluster correlation (Kish, 1965; Cochran, 1977). This correlation is posilive if the characteristics of persons within a cluster are more closely related than those of persons randomly chosen from the population. When the cluster is defined to be the elhnic group, the intracluster correlation is about 0.1 (for both education and $\log$ wages). This correlation increases to 0.2 when the cluster is defined to be type-j ethrics living in neighborhood $k$. Put differently, the neighborhood provides additional information about the skill distribution of persons in a particular ethnic group. 
As with the analysis of Census data, I use two measures of skills, educational attainment and the log wage rate. Each NLSY respondent in 1979 reported the father's education and occupation (which was coded using the 1970 Census codes). I constructed a wage for each father by matching the father's occupation code with the average log wage in the occupation, as reported by the 1970 Census.

To obtain a measure of ethnic capital, I used the 1/100 1980 U.S. Census to calculate the mean educational attainment and mean log wage for each of the ethnic groups in the parents' generation. ${ }^{26}$ The Census data report the ancestral background of U.S.-born residents (obtained from questions resembling the self-reported ethnic background in the NLSY). To increase the probability that the average skills of the ethric milieu corresponded to that in which the NLSY respondents were raised, I restrict the 1980 Census sample to men aged 35-64.

Table 7 reports the summary statistics of the variables used in the analysis. There are sizable ethnic differentials in educational attainment and log wages among NLSY respondents and their parents. Table 8 reports the estimates of the ethnic capital model. The coefficients in the first column of the top panel reveal that the educational attainment of NLSY respondents depends on both the father's education and on the mean education of the ethnic group in the parent's generation. The estimated rate of mean convergence is 0.44 . The introduction of a vector of 510 county dummies in the second column reduces both of the coefficients somewhat; the parental coefficient falls from 0.24 to 0.2 and the ethric capital coefficient falls from 0.20 to 0.14 . Column

\footnotetext{
${ }^{26}$ The ethnic characteristics are calculated using a 20 percent random sample of the $5 / 100$ A File of the 1980 Public Use Sample. I also constructed comparable ethnic characteristies from within the NLSY itself. Although the findings do not depend on which measure of ethnic capital is used, I only report the regressions that use the Census measure (which are calculated over much larger samples and contain less sampling error).
} 
3 investigates the relationship between ethnic capital and neighborhoods by introducing a vector of 1,937 dummies indicating the zip code of residence. ${ }^{27}$ The parental coefficient declines further to 0.17 and the ethnic capital effect evaporates (the coefficient falls to 0.04 ). Net of neighborhood effects, therefore, the rate of mean convergence is only 0.21 , about half the size of the gross rate, and the decline is mostly due to the weakening of the ethnic capital effect. The

NLSY results, therefore, strongly confirm the implications of the analysis of the Census neighborhood data. ${ }^{28}$

The remaining two panels of Table 8 reestimate the model using the $(\log )$ wage and the adjusted wage. The estimate of the rate of mean convergence using the log wage is 0.70 , which is higher than the one found in the Census. The introduction of county dummies reduces the rate of mean convergence to 0.57 , with the ethric capital coefficient remaining unchanged. Finally, the introduction of neighborhood fixed effects reduces the coefficient of ethnic capital to 0.05 , and is statistically insignificant. Note, however, that the coefficient of parental capital has declined by

\footnotetext{
${ }^{27}$ Of the 1,937 zip code fixed eflects included in the educational altainment regressions, there are 900 zip codes with 1 observation, 256 with 2, 168 with 3,123 with 4, and the remainder have 5 or more observations. Of the 1,453 zip code fived effects included in the log wage regressions, there are 733 zip codes with 1 observation, 223 with 2, 140 with 3,80 with 4, and the remainder have 5 or more observations. A regression of educational attainment (or $\log$ wages) of the NLSY respondents on a vector of zip code dummies has an R-squared of about 0.4 , so that about 60 percent of the variance in educational attainment and $\log$ wages can be attributed to within-zip code variation. Over 80 percent of the variance in these variables, however, can be attributed to within-county variation.

${ }^{28}$ It is also possible to estimate Census-type semi-aggregate regressions on the NLSY data, so that the regressions omit the worker's parental background. When educational attainment is the dependent variable, the coefilicient of the ethnic capital variable (and standard error) is $0.438(0.047)$ in the model which does not include either county or neighborhood dummies; $0.329(0.030)$ in the model which includes county dummies; and $0.173(0.029)$ in the model which includes zip code dummies. This pattern of coeficients closely mirrors the results documented in the Census dala. A similar pattern is obtained in the log wage regressions.
} 
about 0.13 units, which indicates that the geographic distribution of NLSY respondents is not consistent with the skill-invariance assumption. ${ }^{29}$

The last column of Table 8 shows what happens to the parental and ethnic capital coefficients when I introduce a small vector of neighborhood characteristics (rather than zip code dummies) to control for neighborhood effects. Because the NLSY file does not contain any population estimates of economic or social characteristics in the zip code, all neighborhoodspecific variables must be calculated from within the data and contain substantial sampling error. I estimated the mean education and log wage of the parents of NLSY respondents in each zip code. Controlling for these two characteristics reduces the ethnic capital coefficient by about 0.05 units in the education regression and by almost 0.3 units in the log wage regression. As with the Census, a small vector of neighborhood characteristics which are common to all persons living in the neighborhood helps explain why the ethnic capital variable matters (particularly in the log wage regressions). ${ }^{30}$

IV. Ethnic Capital and the Ethnic Composition of the Neighborhood

${ }^{29}$ In particular, highly-skilled type-j ethnics tend to cluster in wealthier neighborhoods, while lessskilled type-j ethnics cluster in poorer neighborhoods.

${ }^{30}$ It is of interest to nole that the results do not change substantially when the model is estimated on the subsample of NLSY respondents who were aged 141018 years old at the time of the initial interview in 1979. The residential location decision for these young persons was probably made by their parenis, so that the neighborhood fixed effects are less likely to be endogenous. In the educalional altainment regressions which do not include neighborhood fixed effects, the parental coeficient (and standard error) was $0.235(0.009)$ and the ethnic capital coefficient was $0.097(0.026)$. The inclusion of neighborhood fixed effects changed the coefficients to $0.170(0.007)$ and $0.017(0.032)$, respectively. In the log wage regressions which do not include neighborhood fixed effects, the parenial and ethnic capital coefficients were $0.343(.048)$ and $0.498(0.111)$. Including neighborhood fixed effects changed thesc coefficients to $0.202(0.043)$ and $0.054(0.160)$. 
The evidence suggests that, to a large extent, the ethnic capital effect summarizes the impact of neighborhood characteristics (common to all the residents of the neighborhood) on the intergenerational transmission process. In view of this result, it is worth asking if ethnicity per se plays any role in intergenerational mobility, above and beyond the influence of parents and neighborhoods:

Ethnicity is likely to play a more important role among persons who grow up in a segregated ethnic environment. After all, these persons will probably experience (and be influenced by) more frequent social, cultural, and economic intra-group contacts. The analysis in the preceding section ignored this implication of the model because it assumed that the ethnic capital coefficient was constant across workers. To determine if ethnicity plays an independent role among workers raised in segregated neighborhoods, I now allow the ethnic capital coefficient to vary according to the extent of residential segregation in the neighborhood.

In particular, I interact both the ethnic capital variable and the parental skills variable (when available) with dummies indicating the proportion of persons in the neighborhood who share the same ethnic backgrourid. The regression model also includes the dummy variables indicating the proportion of the neighborhood's population who belong to the respondent's ethnic group (so as to allow for different constant terms). Finally, I estimate the models both with and without neighborhood fixed effects. ${ }^{31}$

\footnotetext{
${ }^{31}$ I did not interact the neighborhood effects with the dummy variables describing the proportion of persons in the neighborhood who have the same ethnic background as the worker. This restriction helps to isolate the impact of ethnic capital among persons who live in the same neighborhood (and hence were exposed to the same overall neighborhood characteristics). I also estimated the models by simply interacting the fraction of persons in a neighborhood who have the same ethnicity with the relevant variables and obtained qualitatively similar results. Table 9 indicates, however, that there are strong nonlinearities in the relationship between the ethnic capital coefficient and the extent of residential segregation. Moreover, there is a great deal of sampling error in the residential segregation statistics. As a result, I prefer the specification that clusters persons into a small number of neighborhood types.
} 
The evidence is summarized in Table 9. Consider initially the results obtained from the 1970 Census file. Even after controlling for neighborhood effects, both the education and log wage regressions show that the rate of mean convergence is larger among persons who live in highly segregated neighborhoods. The education regressions, for example, indicate that the net rate of mean convergence is 0.15 for those who live in neighborhoods where none of the neighbors share the same ethnic background; 0.23 for those who live in neighborhoods where at most 15 percent of the population share the same ethnic background; and 0.27 for those who live in neighborhoods where over 15 percent of the population has the same ethnic background. ${ }^{32}$ In the log wage regressions, the respective statistics are $0.13,0.29$, and 0.38

It is worth stressing that these estimates of the rate of mean convergence net out neighborhood effects. If the impact of parental skills is constant across neighborhoods, the evidence suggests that ethnicity might be playing an important role for persons who live in segregated neighborhoods, above and beyond the influence of parents and neighborhoods.

This implication is partially confirmed by the analysis of the NLSY data, where the rate of mean convergence can be decomposed into the parental and ethnic effects. The educational attainment regressions, for instance, show that (even after controlling for neighborhood fixed effects) the ethnic capital coefficient increases from 0.05 for children who grew up in areas where fewer than 5 percent of the non-related neighbors have the same ethnic background to 0.12 for

\footnotetext{
${ }^{32}$ The results are not sensitive to the particular definition of residential segregation. This particular breakdown, as well as the breakdown of neighborhoods in the NLSY data, was chosen because it provided a reasonable number of observations for each tope of neighborhood. In the Census data, there were 27,006 persons who lived in the most integrated neighborhoods, 18,676 who lived in the "mixed" neighborhoods, and 8,021 who lived in the most segregated neighborhoods. In the NLSY education regressions, the respective number of observations are 1,999, 2,506, and 3.064. while in the NLSY $\log$ wage regressions, they are $1,189,1,428$, and 1,644 .
} 
children who grew up in areas where at least 33 percent of the neighbors share the same ethnicity. Similarly, the ethnic capital coefficient in the log wage regressions rises from 0.03 for those who grew up in "integrated" neighborhoods to 0.14 for the children raised in the most "segregated" neighborhoods (although many of these coefficients have large standard errors).

The NLSY results suggest that not only does the ethnic capital coefficient increase as the neighborhood becomes more segregated, but also that the coefficient of parental skills decreases. The log wage regressions, for instance, indicate that the parental coefficient (net of neighborhood effects) declines from 0.32 for persons raised in the most integrated neighborhoods to 0.26 for persons raised in the most segregated neighborhoods. The relative unimportance of parental skills for persons raised in segregated neighborhoods might indicate that group influences "take over" as the neighborhood becomes more segregated.

Because the coefficients of parental skills and ethnic capital move in different directions as persons are raised in more segregated neighborhoods, the rate of mean convergence (net of neighborhood effects) only increases slightly in the NLSY log wage regressions, from 0.35 for persons living in integrated neighborhood to 0.40 for persons raised in segregated neighborhoods. In the educational attainment regressions, however, the net rate of mean convergence is roughly the same (around 0.25 ) across the various types of neighborhoods.

\section{Ethnic Capital and Measurement Error}

Many of the results presented in this paper are consistent with a different interpretation of the ethnic capital effect. Suppose that parental skills are measured with error. The ethnic mean then provides a very good instrument for parental skills. As a result, part of the parental influence on intergenerational mobility would be captured by the coefficient of the ethnic capital variable, 
even if ethnic capital did not enter the model (see Borjas, 1992, for a formal derivation of the biases introduced by measurement error). The greater the noise-to-signal ratio in parental skills, the greater the ethnic capital coefficient.

This interpretation of the results is particularly important in light of recent evidence that measurement error in parental skills imparts a sizable downward bias on the correlation between the earnings of fathers and sons (Joseph G. Altonji and Thomas A. Dunn, 1991; Solon, 1992; and David J. Zimmerman, 1992). Prior to these studies, it was generally believed that the coefficient of parental skills in an intergenerational transmission equation was on the order of 0.2 (see, for example, the survey by Gary S. Becker and Nigel Tomes, 1986). The recent studies, which typically use panel data to average parental earnings over a number of years (and thus "wash out" the measurement error introduced by transitory changes in earnings), report much higher coefficients, on the order of 0.3 to 0.4 .

The empirical results presented in this paper suggest transmission coefficients (as defined by the rate of mean convergence) that are typically above 0.4 . In fact, the rate of mean convergence was roughly 0.5 to 0.7 for children raised in segregated neighborhoods. Taken at face value, therefore, the evidence suggests that ethnic capital might play an important role even if the intergenerational correlation between parents and children was as high as 0.3 to 0.4 .

The NLSY data permit a more detailed analysis of some of the biases introduced by measurement error. As noted earlier, there are a large number of siblings in the data, with each sibling independently reporting ethnic background, as well as the parent's education and occupation. The correlation among the siblings' responses is high, but it is far from unity. For example, the correlation between a sibling's report of the father's education and the father's average educational attainment as reported by all other siblings is 0.9 ; the respective statistic for 
the father's occupational earnings is 0.8 ; and nearly 30 percent of the respondents identify most with an ethnic background which differs from the "main" ancestry reported by at least one other sibling (although typically the other siblings report the alternative ancestry as a second or third ethnic background). The availability of other sources of information on parental skills and ethnic background suggests that these alternative measures of the variables can be used as instruments in the intergenerational transmission equation. The IV estimates of the transmission parameter can then be used to assess the practical importance of the bias introduced by measurement error in parental skills and ethnic background. ${ }^{33}$

I restrict the analysis to NLSY respondents who have at least one sibling in the data. For those who have only one sibling ( 58 percent of the sample), the instruments are given by the sibling's response. For those who have more than one sibling, the instruments are defined as the average response of all other siblings. The instruments are the average skills of the father (either educational attainment or log occupational wage) as reported by the other siblings in the data, and a set of dummy variables indicating the ethnic background of the other siblings. ${ }^{34}$ The regressions use the IV-random effects estimator proposed by Jerry A. Hausman and William E. Taylor $(1981) \cdot .^{35}$

\footnotetext{
${ }^{33}$ Orley Ashenfelter and Alan B. Kueger (1992) use this methodology to analyze the impact of measurement error in educational attainment on estimates of the rate of return to schooling. Their analysis suggests that measurement error imparts a sizable downward bias on estimates of the rate of retum to schooling.

${ }^{34} 1$ created a vector of dummy variables indicating the ethnic group reported by each sibling in the data. The instument is formed by averaging this vector over all other siblings, so that it can be interpreted as the probability that the other siblings report a particular ethnic background.

${ }^{35}$ The model is estimated in two stages. In the first stage, the children's skills are regressed on the father's skills, other explanatory variables (age, gender, etc.), and a vector of dummy variables indicating the self-reported ethnic background. The first-stage model is estimaled using instnumental variables. The second stage consists of a GLS regression in which the estimated coefficients of the ethnic dummy variables are regressed on the ethnic capital variable. The regressions that control for
} 
A comparison of the IV estimates in the first row of Table 10 with the corresponding OLS estimates in Table 8 indicates that the coefficient of parental skills increases both in the education regression (from 0.24 to 0.28 ), and in the log wage regression (from 0.38 to 0.48 ). The results also indicate that the IV estimates of the ethnic capital coefficient remain sizable and significant. In particular, the coefficients are 0.18 and 0.30 in the education and log wage regressions respectively, only slightly below the OLS estimates reported in Table 8. It is evident, therefore, that measurement error in parental skills or in ethnic background cannot account for the results..

The remaining rows of the table interact the measures of parental skills and ethnic capital with dummy variables indicating the proportion of persons in the zip code who share the same ethnic background as the worker. The coefficients in Table 10 resemble those reported earlier, particularly in the education regressions. The coefficient of parental skills is smaller and the ethnic capital coefficient is larger among workers who grew up in segregated neighborhoods (even after controlling for neighborhood effects). The impact of parental education, for instance, declines from 0.29 to 0.14 (in an IV model which includes neighborhood effects) for workers who live in more segregated neighborhoods; while the ethric capital coefficient rises from 0.01 to 0.17 . In view of the small samples sizes and large standard errors, however, many of these differences are not very significant. ${ }^{36}$

neighborhood effects use a data set which has been differenced from the within zip-code means in the first stage.

\footnotetext{
${ }^{36}$ Although the evidence is nol consistent with an explanation that stresses classical measurement error in parental skills or ethnic background, there are other measurement problems which may account for some of the results. I have focused on a one-factor model where one particular type of skills (either educational attainment or the $\log$ wage) is transmitled across generations. There is evidence that this one-factor approach does not provide a satisfactory explanation of the process of intergenerational mobility. Altonji and Dunn (1991) report that the correlation in eamings among siblings is larger than would be expected given the size of the correlation between parents and children. This result suggests that perhaps a vector of traits is being transmitted, so that the ethnic capital varisble could be proxying for an aggregate measure of these trails.
} 


\section{Summary}

It is increasingly evident that ethnic skill differentials tend to persist from generation to generation. Part of the correlation arises because of the linkage between parental skills and the skills of children: Even if ethnicity did not matter, the children of skilled parents are likely to have above-average skills. This correlation, however, is not sufficiently high to account for the sluggish rate at which the mean skills of ethnic groups converge over time. To explain the slow rate of convergence, recent work borrows from the new growth literature and stresses the importance of ethnic externalities in the human capital accumulation process. This ethnic spillover implies that the skills of ethnic children depend not only on parental skills, but also on the mean skills of the ethnic group in the parent's generation. The intergenerational transmission of this ethnic fixed effect explains why it takes a relatively long time for ethnic skill differentials to converge.

This paper investigates the nature of the ethnic externality. The study focuses on one possible channel through which the ethnic externality might operate, the ethnic neighborhood. Using the Neighborhood File of the 1970 U.S. Census and the National Longitudinal Surveys of Youth, I documented substantial residential segregation by ethnicity. Even though only 16.6 percent of the population in 1970 was first- or second-generation, the typical immigrant resided in a neighborhood that was 32.7 percent first- or second-generation, and the respective statistic for second-generation workers was 28.2 percent. In addition, there was a strong likelihood that persons belonging to a particular ethnic group reside in a neighborhood where a relatively high number of persons share the same ethnic group. 
The empirical analysis indicated that the rate of mean convergence in the skills of ethnic groups was significantly reduced after controlling for neighborhood fixed effects. This finding indicates that much of the ethnic capital effect works through the fact that low-income ethnic groups cluster in low-income neighborhoods, and these neighborhood effects influence intergenerational mobility. The analysis, however, also revealed that neighborhood effects cannot account for the entire impact of ethnicity on intergenerational mobility, particularly for persons residing in ethnically segregated neighborhoods. Ethnicity has an impact above and beyond both parental and neighborhood effects for persons who are frequently exposed to a particular ethnic environment.

There are many related issues and questions that are not addressed in this paper. For instance, what happens to the nature and impact of ethnic externalities as the groups intermarry? How do the different ethnic influences clash when disparate ethnic and racial groups cluster in the same neighborhoods? What are the policy implications of the interactions between ethnic externalities, residential segregation, and intergenerational mobility? Because of the underlying significance of these questions, the study of the links between race, ethnicity, and human capital externalities is sure to remain a fertile ground for future research. 


\section{REFERENCES}

Alba, Richard D. Ethnic Identity: The Transformation of White America. New Haven, Conn:: Yale University Press, 1990.

Altonji, Joseph G. and Dunn, Thomas A. "Relationship Among the Family Incomes and Labor Market Outcomes of Relatives," Research in Labor Economics, 1991, 12, pp. 269-310.

Ashenfelter, Orley and Krueger, Alan B. "Estimates of the Economic Return to Schooling from a New Sample of Twins." Unpublished Manuscript, Princeton University, August 1992.

Barro, Robert J. and Sala-i-Martin, Xavier. "Convergence," Journal of Political Economy, April 1992, 100(2), pp. 223-251.

Becker, Gary S. and Tomes, Nigel. "Human Capital and the Rise and Fall of Families," Journal of Labor Economics, July 1986, 6(j, Part 2), pp. S1-S39.

Bean, Frank D. and Tienda, Marta. The Hispanic Population of the United States. New York: Russell Sage Foundation, 1987.

Borjas, George J. "Ethnic Capital and Intergenerational Mobility," Quarterly Journal of Economics, February 1992, 107(1), pp. 123-150.

Economics, January 1993, 11(1, Part 1), pp. 113-135.

"Long-Run Convergence of Ethnic Skill Differentials: The Children and Grandchildren of the Great Migration," Industrial and Labor Relations Review, July 1994, 47(4), pp. 553-573.

Case, Anne C. and Katz, Lawrence F. "The Company You Keep: The Effects of Family and Neighborhood on Disadvantaged Youths." Unpublished Manuscript, National Bureau of Economic Research, May 1991.

Cochran, William G. Sampling Techniques. New York: John Wiley \& Sons, 1977.

Coleman, James S. "Social Capital in the Creation of Human Capital," American Journal of Sociology, 1988, 94(Supplement), pp. S95-S120.

Press, 1990

Foundations of Social Theory. Cambridge, MA: Harvard University

Conlisk, John. "An Exploratory Model of the Size Distribution of Income," Economic Inquiry, July $1977,15(3)$, pp. 345-366. 
Corcoran, Mary; Gordon, Roger; Laren, Deborah and Solon, Gary. "The Association Between Men's Economic Status and Their Family and Community Origins," Journal of Human Resources, Fall 1991, 27(4), pp. 575-601.

Crane, Jonathan. "The Epidemic Theory of Ghettos and Neighborhood Effects on Dropping Out and Teenage Childbearing," American Joumal of Sociology, March 1991, 96(5), pp. 1226-1259.

Denton, Nancy A. and Massey, Douglas S. "Hypersegregation in United States Metropolitan Areas--Black and Hispanic Segregation Along 5 Dimensions," Demography, August $1989, \underline{26}(3)$, pp. 373-391.

Evans, William N.; Oates, Wallace E. and Schwab, Robert M. "Measuring Peer Group Effects: A Study of Teenage Behavior," Journal of Political Economy, October 1992, 100(5), pp. 966-991.

Hausman, Jerry A. and Taylor, William E. "Panel Data and Unobservable Individual Effects," Econometrica, November 1981, 49(6), pp. 1377-1398.

Holzer, Harry J. "Search Method Use by Unemployed Youth," Joumal of Labor Economics, January 1988, 6(1), pp. 1-20.

Hughes, Mark Alan, and Fadden, Janice Fanning. "Residential Segregation and the Economic Status of Black Workers: New Evidence for an Old Debate," Journal of Urban Economics, January 1991, 29(1), pp. 28-49.

Jencks, Christopher and Meyer, Susan E. "The Social Consequences of Growing Up in a Poor Neighborhood: A Review," in Laurance E. Lynn and Michael G. H. McGeary, eds., Inner City Poverty in the United States. Washington, D.C.: National Academy Press, 1990, pp. 111186.

Kish, Leslie. Survey Sampling. New York: John Wiley \& Sons, 1965.

Loury, Glenn C. "A Dynamic Theory of Racial Income Differences," in Phyllis A. Wallace and Annette A. LaMond, eds., Women. Minorities, and Employment Discrimination. Lexington. MA: Lexington Books, 1977, pp. 153-186.

Lucas, Robert E. "On the Mechanics of Economic Development, Joumal of Monetary Economics, July 1988, 22(1), pp. 3-42.

Lundberg, Shelly and Startz, Richard. "On the Persistence of Racial Inequality." Unpublished Manuscript, University of Washington, 1992.

Manski, Charles F. "Identification of Endogenous Social Effects: The Reflection Problem," Review of Economic Studies, July 1993, 60(3), pp. 531-542. 
McKinney, Scott and Schnare, Ann B. "Trends in Residential Segregation by Race: 19601980," Journal of Urban Economics, November 1989, 26(3), pp. 269-280.

Rauch, James E. "Productivity Gains from Geographic Concentration of Human Capital: Evidence from the Cities," Journal of Urban Economics, November 1993, 34(3), pp. 380-400.

Romer, Paul M. "Increasing Returns and Long-Run Growth," Joumal of Political Economy, October 1986, 94(5), pp. 1002-1037.

Solon, Gary R. "Intergenerational Income Mobility in the United States," American Economic Review, June 1992, 82(3), pp. 393-408.

U.S. Bureau of the Census. Supplement No 1 to Public Use Samples of Basic Records from the 1970 Census: Description and Technical Documentation. Washington, DC: U.S. Government Printing Office, 1973.

Wilson, William Julius. The Truly Disadvantaged: The Inner City the Underclass, and Public Policy. Chicago: University of Chicago Press, 1987.

Zimmerman, David J. "Regression Toward Mediocrity in Economic Stature," American Economic Review, June 1992, 82(3), pp. 409-429. 


\section{TABLE 1. RESIDENTIAL SEGREGATION IN 1970 CENSUS}

Percent of Population in Neighborhood that is:

\begin{tabular}{lrrrrr}
\cline { 2 - 6 } $\begin{array}{l}\text { Neighborhood Characteristics } \\
\text { of Average Person in: }\end{array}$ & $\begin{array}{c}\text { First } \\
\text { Generation }\end{array}$ & $\begin{array}{c}\text { First or } \\
\text { Second } \\
\text { Generation }\end{array}$ & Black & Hispanic & $\begin{array}{c}\text { Sample } \\
\text { Size }\end{array}$ \\
\hline 1st Generation & 15.3 & 32.7 & 6.9 & 10.2 & 63,099 \\
2nd Generation & 6.7 & 28.2 & 4.3 & 5.2 & 156,134 \\
3rd Generation & 3.8 & 13.8 & 11.7 & 3.9 & 905,213 \\
& & & & & \\
Hispanics: & 22.2 & 36.7 & 6.5 & 35.0 & 10,713 \\
1st Generation & 9.4 & 27.3 & 5.1 & 33.0 & 10,801 \\
2nd Generation & 8.9 & 21.9 & 11.4 & 28.8 & 25,202 \\
3rd Generation & & & & & \\
& 3.1 & 8.0 & 54.7 & 3.7 & 109,533 \\
3rd Generation: & 3.7 & 14.4 & 5.6 & 3.1 & 771,359
\end{tabular}

Notes: The "white" sample includes all non-black, non-Hispanic third generation workers. The population proportions are as follows: immigrants, 4.8 percent; first or second generation, 16.6 percent; blacks, 11.1 percent; and Hispanics, 4.4 percent. 
TABLE 2. RESIDENTIAL SEGREGATION IN 1970 CENSUS, BY NATIONAL ORIGIN GROUP

\begin{tabular}{|c|c|c|c|c|c|c|c|}
\hline \multirow[b]{3}{*}{ National Origin } & \multirow{3}{*}{$\begin{array}{l}\text { Percent of } \\
\text { Population in } \\
\text { Group }\end{array}$} & \multicolumn{3}{|c|}{ First Generation } & \multicolumn{3}{|c|}{ Second Generation } \\
\hline & & \multicolumn{2}{|c|}{$\begin{array}{c}\text { Percent of Population } \\
\text { in Neighborhood That } \\
\text { is: }\end{array}$} & \multirow[b]{2}{*}{$\begin{array}{c}\text { Sample } \\
\text { Size }\end{array}$} & \multicolumn{2}{|c|}{$\begin{array}{c}\text { Percent of Population } \\
\text { in Neighborhood That } \\
\text { is: }\end{array}$} & \multirow[b]{2}{*}{$\begin{array}{c}\text { Sample } \\
\text { Size }\end{array}$} \\
\hline & & $\begin{array}{l}\text { Ist or } 2 \text { nd } \\
\text { Generation }\end{array}$ & $\begin{array}{l}\text { Of Same } \\
\text { Ethnicity }\end{array}$ & & $\begin{array}{l}\text { lst or } 2 \text { nd } \\
\text { Generation }\end{array}$ & $\begin{array}{l}\text { Of Same } \\
\text { Ethnicity }\end{array}$ & \\
\hline Austria & 0.6 & 34.5 & 2.0 & 883 & 30.1 & 2.1 & 6007 \\
\hline Azores & 0.04 & 37.1 & 8.0 & 184 & 30.5 & 3.5 & 320 \\
\hline Belgium & 0.07 & 28.9 & 0.4 & 250 & 21.8 & 0.7 & 573 \\
\hline British West Indics & 0.03 & 24.8 & 0.8 & 175 & 24.0 & 0.8 & 188 \\
\hline Canada & 1.8 & 25.7 & 6.2 & 6843 & 24.8 & 7.4 & 13085 \\
\hline Cuba & 0.3 & 48.7 & 21.3 & 3119 & 27.6 & 4.7 & 270 \\
\hline China & 0.2 & 38.5 & 9.2 & 1617 & 33.5 & 6.2 & 635 \\
\hline Czechoslovakia & 0.5 & 34.6 & 2.3 & 797 & 25.6 & 2.9 & 4571 \\
\hline Denmark & 0.2 & 24.9 & 0.5 & 289 & 20.2 & 0.9 & 1608 \\
\hline England & 0.8 & 24.3 & 1.5 & 3113 & 23.5 & 1.5 & 6367 \\
\hline Finland & 0.1 & 29.1 & 1.5 & 194 & 25.5 & 3.9 & 1200 \\
\hline France & 0.2 & 28.7 & 0.4 & 811 & 23.8 & 0.3 & 1184 \\
\hline Germany & 1.7 & 27.2 & 2.9 & 5930 & 21.9 & 3.2 & 13089 \\
\hline Greece & 0.3 & 38.3 & 2.6 & 1147 & 28.3 & 1.1 & 1913 \\
\hline Hungary & 0.4 & 34.3 & 2.6 & 1020 & 28.0 & 1.9 & 3472 \\
\hline Ireland & 0.8 & 36.2 & 4.6 & 1434 & 31.3 & 3.3 & 7137 \\
\hline Italy & 2.8 & 37.7 & 15.3 & 5193 & 32.0 & 12.1 & 26476 \\
\hline Jamaica & 0.06 & 28.4 & 2.2 & 507 & 22.3 & 1.5 & 163 \\
\hline Japan & 0.2 & 26.1 & 3.2 & 1020 & 33.7 & 12.6 & 1716 \\
\hline Larvia & 0.04 & 27.0 & 0.2 & 245 & .3 .1 & 0.1 & 260 \\
\hline Lebanon & 0.05 & 27.0 & 0.3 & 118 & 23.7 & 0.4 & 476 \\
\hline Lithuania & 0.2 & 36.2 & 3.7 & 325 & 30.6 & 1.5 & 2128 \\
\hline Mexico & 1.3 & 35.4 & 22.6 & 5746 & 27.8 & 18.1 & 8412 \\
\hline Netherlands & 0.2 & 23.9 & 1.8 & 689 & 21.5 & 3.9 & 1725 \\
\hline Northem Ireland & 0.1 & 29.4 & 0.3 & 233 & 28.1 & 0.2 & 573 \\
\hline Norway & 0.3 & 28.5 & 1.8 & 422 & 22.1 & 3.0 & 3203 \\
\hline Orher West Indies & 0.04 & 28.8 & 2.5 & 254 & 25.5 & 1.3 & 250 \\
\hline Philippines & 0.2 & 31.0 & 5.9 & 1477 & 30.1 & 6.5 & 606 \\
\hline Poland & 1.7 & 40.2 & 9.1 & 2846 & 32.0 & 7.8 & 15182 \\
\hline Portugal & 0.1 & 40.9 & 11.2 & 654 & 32.7 & 6.8 & 1030 \\
\hline Romania & 0.1 & 38.6 & 0.8 & 373 & 34.5 & 0.7 & 1150 \\
\hline Scotland & 0.3 & 27.5 & 0.7 & 1013 & 24.4 & 0.7 & 2517 \\
\hline Sweden & 0.4 & 29.1 & 1.4 & 445 & 22.3 & 1.7 & 4284 \\
\hline Suitzerland & 0.1 & 26.7 & 0.6 & 315 & 20.3 & 0.8 & 947 \\
\hline Syria & 0.04 & 30.9 & 1.7 & 103 & 27.9 & 0.8 & 387 \\
\hline Turkey & 0.06 & 36.6 & 0.2 & 251 & 33.0 & 0.3 & 459 \\
\hline USSR & 1.2 & 38.8 & 7.0 & 1738 & 34.9 & 7.8 & 12067 \\
\hline Wales & 0.1 & 23.7 & 0.1 & 99 & 21.3 & 0.3 & 529 \\
\hline Yugoslavia & 0.3 & 31.9 & 2.7 & 930 & 25.1 & 2.4 & 2309 \\
\hline Sample of 39 & $\ldots$ & 32.9 & 8.3 & 52802 & 28.3 & 6.6 & 148468 \\
\hline
\end{tabular}

Note: The residential segregation measures give the percent of the population in the neighborhood that belongs 10 the specified ethnic group for the average person in the sample. 
TABLE 3. RESIDENTIAL SEGRECA.TION IN 1970 CENSUS, BY DEMOGRAPHIC CHARACTERISTICS

Percent of Population in Neighborhood that is:

\begin{tabular}{|c|c|c|c|c|c|}
\hline $\begin{array}{l}\text { Neighborhood Characteristics } \\
\text { of Average Person in: }\end{array}$ & $\begin{array}{l}\text { 1st or } 2 \text { nd } \\
\text { Generation }\end{array}$ & Black & Hispanic & $\begin{array}{l}\text { Of Same } \\
\text { Ethnicity }\end{array}$ & Sample Size \\
\hline $\begin{array}{l}\text { 1st Generation } \\
\text { Age: } \\
18-34 \\
35-64\end{array}$ & $\begin{array}{l}31.7 \\
33.2\end{array}$ & $\begin{array}{l}7.9 \\
6.3\end{array}$ & $\begin{array}{r}11.9 \\
9.3\end{array}$ & $\begin{array}{l}8.7 \\
8.2\end{array}$ & $\begin{array}{l}21,532 \\
41,567\end{array}$ \\
\hline $\begin{array}{l}\text { Education: } \\
\text { Less than } 12 \text { years } \\
12 \text { years } \\
13-15 \text { years } \\
16 \text { or more years }\end{array}$ & $\begin{array}{l}35.5 \\
30.8 \\
29.5 \\
29.1\end{array}$ & $\begin{array}{l}7.3 \\
6.6 \\
6.1 \\
6.4\end{array}$ & $\begin{array}{r}13.3 \\
7.8 \\
7.4 \\
5.7\end{array}$ & $\begin{array}{r}11.7 \\
5.8 \\
4.6 \\
3.4\end{array}$ & $\begin{array}{r}30,590 \\
17,000 \\
7,959 \\
7,550\end{array}$ \\
\hline $\begin{array}{l}\text { Year Moved to House: } \\
\text { Before } 1960 \\
1960-1966 \\
1967-1970\end{array}$ & $\begin{array}{l}32.5 \\
33.9 \\
32.1\end{array}$ & $\begin{array}{l}6.3 \\
6.3 \\
7.4\end{array}$ & $\begin{array}{l}7.4 \\
10 \\
11.6\end{array}$ & $\begin{array}{l}7.7 \\
8.8 \\
8.3\end{array}$ & $\begin{array}{l}13,623 \\
18,690 \\
30,786\end{array}$ \\
\hline $\begin{array}{l}\text { 2nd Generation } \\
\text { Age: } \\
\quad 18-34 \\
35-64\end{array}$ & $\begin{array}{l}27.4 \\
28.5\end{array}$ & $\begin{array}{l}4.9 \\
4.1\end{array}$ & $\begin{array}{l}7.6 \\
4.6\end{array}$ & $\begin{array}{l}6.6 \\
6.5\end{array}$ & $\begin{array}{r}31,824 \\
124,310\end{array}$ \\
\hline $\begin{array}{l}\text { Education: } \\
\text { Less than } 12 \text { years } \\
12 \text { years } \\
13-15 \text { years } \\
16 \text { or more years }\end{array}$ & $\begin{array}{l}28.7 \\
28.1 \\
27.4 \\
27.8\end{array}$ & $\begin{array}{l}4.8 \\
3.9 \\
3.9 \\
3.8\end{array}$ & $\begin{array}{l}6.7 \\
4.4 \\
4.6 \\
3.3\end{array}$ & $\begin{array}{l}8.4 \\
6.0 \\
4.7 \\
4.2\end{array}$ & $\begin{array}{l}61,896 \\
56,725 \\
19,311 \\
18,212\end{array}$ \\
\hline $\begin{array}{l}\text { Year Moved to House: } \\
\text { Before } 1960 \\
1960-1966 \\
1967-1970\end{array}$ & $\begin{array}{l}29.4 \\
28.5 \\
26.3\end{array}$ & $\begin{array}{l}4.4 \\
3.9 \\
4.3\end{array}$ & $\begin{array}{l}4.3 \\
5.4 \\
6.2\end{array}$ & $\begin{array}{l}7.4 \\
6.5 \\
5.4\end{array}$ & $\begin{array}{l}65,585 \\
40,926 \\
44,623\end{array}$ \\
\hline $\begin{array}{l}\text { 3rd Generation } \\
\text { Age: } \\
18-34 \\
35-64\end{array}$ & $\begin{array}{l}14.5 \\
13.2\end{array}$ & $\begin{array}{l}11.4 \\
11.9\end{array}$ & $\begin{array}{l}4.1 \\
3.7\end{array}$ & $\ddot{-}$ & $\begin{array}{l}425,477 \\
479,736\end{array}$ \\
\hline $\begin{array}{l}\text { Education: } \\
\text { Less than } 12 \text { years } \\
12 \text { years } \\
13-15 \text { years } \\
16 \text { or more years }\end{array}$ & $\begin{array}{l}11.5 \\
14.5 \\
15.9 \\
17\end{array}$ & $\begin{array}{r}16.5 \\
9.4 \\
8.1 \\
6.7\end{array}$ & $\begin{array}{l}4.3 \\
3.6 \\
3.9 \\
3.3\end{array}$ & $\begin{array}{l}-- \\
-- \\
-\end{array}$ & $\begin{array}{r}346,392 \\
334,888 \\
129,884 \\
94,049\end{array}$ \\
\hline $\begin{array}{l}\text { Year Moved to House: } \\
\text { Before } 1960 \\
1960-1966 \\
1967-1970\end{array}$ & $\begin{array}{l}13.9 \\
13.6 \\
13.9\end{array}$ & $\begin{array}{l}11.4 \\
12.3 \\
11.4\end{array}$ & $\begin{array}{l}3.3 \\
3.8 \\
4.3\end{array}$ & $\begin{array}{l}-- \\
-- \\
--\end{array}$ & $\begin{array}{l}242,945 \\
255,798 \\
406,470\end{array}$ \\
\hline
\end{tabular}


TABLE 4. RESIDENTIAL SEGREGATION IN NL SY, BY NATIONAL ORIGIN GROUP

\begin{tabular}{|c|c|c|c|}
\hline Ethnicity & $\begin{array}{l}\text { Percent of } \\
\text { Population in } \\
\text { Group }\end{array}$ & $\begin{array}{c}\text { Percent of Population in } \\
\text { Neighborhood with Same } \\
\text { Ethnic Background }\end{array}$ & Sample Size \\
\hline American & 7.6 & 18.2 & 743 \\
\hline American Indian & 5.9 & 12.9 & 624 \\
\hline Asian Indian & 0.2 & 2.0 & 22 \\
\hline Black & 14.9 & 63.4 & 3055 \\
\hline Chinese & 0.2 & 3.5 & 26 \\
\hline Cuban & 0.4 & 33.3 & 117 \\
\hline English & 18.9 & 23.9 & 1587 \\
\hline Filipino & 0.4 & 5.0 & 44 \\
\hline French & 3.5 & 5.6 & 316 \\
\hline German & 17.4 & 25.7 & 1420 \\
\hline Greek & 0.4 & 7.2 & 31 \\
\hline Hawaiian & 0.1 & 0.2 & 20 \\
\hline Irish & 11.0 & 14.3 & 956 \\
\hline Italian & 6.2 & 16.3 & 498 \\
\hline Japanese & 0.2 & 0.0 & 20 \\
\hline Korean & 0.1 & 0.0 & 6 \\
\hline Mexican & 4.1 & 50.3 & 1174 \\
\hline Other Hispanic & 0.9 & 9.3 & 214 \\
\hline Polish & 3.1 & 12.8 & 242 \\
\hline Portuguese & 0.6 & 19.7 & 97 \\
\hline Puerto Rican & 1.2 & 29.8 & 328 \\
\hline Russian & 0.6 & 0.3 & 47 \\
\hline Scottish & 1.5 & 4.6 & 122 \\
\hline Vietnamese & 0.0 & 0.0 & 1 \\
\hline Welsh & 0.5 & 1.0 & $3:$ \\
\hline All & --- & 30.4 & 11745 \\
\hline
\end{tabular}


TABLE 5. SKILLS OF IMMIGRANT AND SECOND GENERATION WORKERS

\begin{tabular}{|c|c|c|c|c|c|c|}
\hline \multirow[b]{2}{*}{ Country of Origin: } & \multicolumn{3}{|c|}{ Immigrants in 1940 Census } & \multicolumn{3}{|c|}{ 2nd Generation in 1970 Census } \\
\hline & $\begin{array}{l}\text { Educational } \\
\text { Attainment }\end{array}$ & Log Wage & $\begin{array}{c}\text { Sample } \\
\text { Size } \\
\end{array}$ & $\begin{array}{l}\text { Educational } \\
\text { Attainment }\end{array}$ & Log Wage & $\begin{array}{c}\text { Sample } \\
\text { Size }\end{array}$ \\
\hline Austria & 6.7 & -0.349 & 1210 & 11.9 & 1.550 & 2134 \\
\hline Azores & 5.0 & -0.672 & 63 & 9.6 & 1.232 & 104 \\
\hline Belgium & 7.8 & -0.483 & 138 & 11.4 & 1.475 & 197 \\
\hline British West Indies & 8.1 & -0.810 & 58 & 12.2 & 1.368 & 68 \\
\hline Canada & 9.2 & -0.427 & 2741 & 12.0 & 1.431 & 4720 \\
\hline China & 6.3 & -1.176 & 139 & 13.6 & 1.447 & 206 \\
\hline Cuba & 8.6 & -0.655 & 42 & 12.0 & 1.372 & 82 \\
\hline Czechoslovakia & 6.8 & -0.345 & 817 & 11.3 & 1.453 & 1749 \\
\hline Denmark & 9.2 & -0.392 & 327 & 12.0 & 1.405 & 553 \\
\hline England & 9.5 & -0.313 & 1656 & 12.5 & 1.508 & 2255 \\
\hline Finland & 6.5 & -0.539 & 244 & 11.3 & 1.457 & 390 \\
\hline France & 9.0 & -0.430 & 248 & 12.3 & 1.450 & 381 \\
\hline Germany & 8.8 & -0.467 & 2943 & 11.7 & 1.463 & 4558 \\
\hline Greece & 6.9 & -0.737 & 518 & 12.7 & 1.484 & 694 \\
\hline Hungary & 7.1 & -0.378 & 809 & 11.7 & 1.509 & 1298 \\
\hline Ireland & 8.3 & -0.445 & 1326 & 12.3 & 1.508 & 2645 \\
\hline Italy & 5.4 & -0.475 & 4784 & 11.2 & 1.454 & 10148 \\
\hline Japan & 9.5 & -0.849 & 141 & 12.5 & 1.476 & 662 \\
\hline Lithuania & 4.5 & -0.479 & 451 & 12.0 & 1.511 & 766 \\
\hline Mexico & 4.4 & -1.120 & 1192 & 9.2 & 1.133 & 2959 \\
\hline Netherlands & 8.8 & -0.557 & 292 & 11.7 & 1.487 & 623 \\
\hline Northern Ireland & 8.3 & -0.401 & 280 & 12.8 & 1.533 & 200 \\
\hline Norway & 8.6 & -0.441 & 606 & 12.0 & 1.457 & 987 \\
\hline Other West Indies & 8.3 & -0.821 & 119 & 11.9 & 1.353 & 87 \\
\hline Philippines & 7.8 & -1.009 & 233 & 11.9 & 1.268 & 188 \\
\hline Poland & 5.4 & -0.407 & 2610 & 11.3 & 1.492 & 5769 \\
\hline Portugal & 4.7 & -0.577 & 212 & $10 ?$ & 1.357 & 383 \\
\hline Romania & 7.4 & -0.339 & 300 & 13.2 & 1.647 & 428 \\
\hline Scotland & 9.6 & -0.326 & 862 & 12.4 & 1.511 & 901 \\
\hline Sweden & 8.6 & -0.378 & 1038 & 12.3 & 1.503 & 1534 \\
\hline Switzerland & 9.5 & -0.461 & 242 & 12.0 & 1.488 & 329 \\
\hline Syria & 6.7 & -0.547 & 105 & 12.5 & 1.576 & 131 \\
\hline Turkey & 7.2 & -0.523 & 211 & 13.7 & 1.644 & 144 \\
\hline USSR & 7.0 & -0.363 & 2418 & 13.1 & 1.654 & 4313 \\
\hline Wales & 9.4 & -0.426 & 100 & 12.4 & 1.441 & 189 \\
\hline Yugoslavia & 5.4 & -0.340 & 512 & 11.7 & 1.499 & 928 \\
\hline
\end{tabular}




\section{TABLE 6. ESTIMATES OF INTERGENERATIONAL CORRELA? ION IN 1970 CENSUS}

\section{Regressions Using Neighborhood File \\ Regressions Using County Group File}

\begin{tabular}{|c|c|c|c|c|c|c|c|}
\hline \multirow[b]{2}{*}{ Variable } & & & & & & & \\
\hline & (1) & (2) & (3) & (4) & (5) & $(6)$ & (7) \\
\hline \multicolumn{8}{|l|}{ A. Education: } \\
\hline Mean of Group in 1940 & $\begin{array}{c}0.3649 \\
(0.0828)\end{array}$ & - & $\begin{array}{c}0.1707 \\
(0.0457)\end{array}$ & $\begin{array}{l}0.2670 \\
(0.0557)\end{array}$ & $\begin{array}{c}0.3628 \\
(0.0833)\end{array}$ & -- & $\begin{array}{c}0.3316 \\
(0.0709)\end{array}$ \\
\hline $\begin{array}{l}\text { Inciudes Neighborhood } \\
\text { Fixed Effects }\end{array}$ & No & - & Yes & No & - & - & --- \\
\hline $\begin{array}{l}\text { lncludes County Fixed } \\
\text { Effects }\end{array}$ & $\cdots$ & - & - & - & No & --- & Yes \\
\hline $\begin{array}{l}\text { Includes Neighborhood } \\
\text { Characteristics }\end{array}$ & No & - & No & Yes & No & - & No \\
\hline \multicolumn{8}{|l|}{ B. Log Wage } \\
\hline Mean of Group in 1940 & $\begin{array}{c}0.4549 \\
(0.0781)\end{array}$ & $\begin{array}{c}0.3974 \\
(0.0662)\end{array}$ & $\begin{array}{c}0.2191 \\
(0.0578)\end{array}$ & $\begin{array}{c}0.2474 \\
(0.0362)\end{array}$ & $\begin{array}{c}0.4607 \\
(0.0874)\end{array}$ & $\begin{array}{c}0.3710 \\
(0.0694)\end{array}$ & $\begin{array}{c}0.3938 \\
(0.0772)\end{array}$ \\
\hline $\begin{array}{l}\text { lncludes Skill-Adjusted } \\
\text { Wage Level }\end{array}$ & No & Yes & No & Yes & No & Yes & No \\
\hline $\begin{array}{l}\text { lncludes Neighborhood } \\
\text { Fixed Effects }\end{array}$ & No & No & Yes & No & - & - & - \\
\hline $\begin{array}{l}\text { Includes County Fixed } \\
\text { Effects }\end{array}$ & - & - & - & -- & No & No & Yes \\
\hline $\begin{array}{l}\text { lncludes Neighborhood } \\
\text { Characteristics }\end{array}$ & No & No & No & Yes & No & No & No \\
\hline \multicolumn{8}{|c|}{ C. Log Wage, Adjusted for Education } \\
\hline Mean of Group in 1940 & $\begin{array}{c}0.2038 \\
(0.0400)\end{array}$ & $\begin{array}{c}0.1767 \\
(0.0321)\end{array}$ & $\begin{array}{c}0.1101 \\
(0.0413)\end{array}$ & $\begin{array}{c}0.1020 \\
(0.0193)\end{array}$ & $\begin{array}{c}0.2132 \\
(0.0511)\end{array}$ & $\begin{array}{c}0.1589 \\
(0.0352)\end{array}$ & $\begin{array}{c}0.1701 \\
(0.0440)\end{array}$ \\
\hline $\begin{array}{l}\text { Includes Skill-Adjusted } \\
\text { Wage Level }\end{array}$ & No & Yes & No & Yes & No & Yes & No \\
\hline $\begin{array}{l}\text { Includes Neighborhood } \\
\text { Fixed Effects }\end{array}$ & No & No & Yes & No &.- & -- & -- \\
\hline $\begin{array}{l}\text { lncludes County Fixed } \\
\text { Effects }\end{array}$ & $\cdots$ & - & $\cdots$ & - & No & No & Yes \\
\hline $\begin{array}{l}\text { Includes Neighborhood } \\
\text { Characteristics }\end{array}$ & No. & No & No & Yes & No & No & No \\
\hline
\end{tabular}

Notes: Standard errors are reported in parentheses; the sample size is 53,703. All regressions iuclude a secondorder polynomial in the worker's age. The neighborhoods characteristics included in column 4 arc: the fraction of persons in the neighborhood with at least 12 years of schooling, the fraction with at least 16 years of schooling, the labor force participation rates of men and women, the unemployment rate, the fraction of persons working in professional occupations, the fraction of families below the por $c$ ty line, and the fraction of families that earn at least $\$ 15,000$ annually. The regressions use a random-effects estimator. 
TABLE 7. SKILLS OF ETHNIC GROUPS IN NLSY

Educational Attainment of:

\begin{tabular}{|c|c|c|c|c|c|c|c|}
\hline National Origin: & $\begin{array}{c}\text { NLSY } \\
\text { Respondents }\end{array}$ & $\begin{array}{l}\text { NLSY } \\
\text { Fathers }\end{array}$ & $\begin{array}{r}\text { Census } \\
\text { Men }\end{array}$ & $\begin{array}{c}\text { NLSY } \\
\text { Respondents }\end{array}$ & $\begin{array}{l}\text { NLSY } \\
\text { Fathers }\end{array}$ & $\begin{array}{c}\text { Census } \\
\text { Men }\end{array}$ & $\begin{array}{c}\text { Sample } \\
\text { Size }\end{array}$ \\
\hline American & 12.4 & 10.9 & 11.2 & 2.099 & 1.292 & 1.945 & 480 \\
\hline American Indian & 12.1 & 10.2 & 11.2 & 1.977 & 1.285 & 1.904 & 429 \\
\hline Asian Indian & 14.0 & 11.9 & 16.7 & 1.684 & 1.464 & 2.180 & 7 \\
\hline Black & 12.8 & 10.1 & 11.0 & 1.948 & 1.177 & 1.852 & 1795 \\
\hline Chinese & 15.2 & 10.0 & 13.8 & 2.403 & 1.146 & 1.955 & 16 \\
\hline Cuban & 13.4 & 11.0 & 11.3 & 2.403 & 1.293 & 1.876 & 69 \\
\hline English & 13.0 & 11.9 & 12.9 & 2.085 & 1.353 & 2.093 & 1125 \\
\hline Filipino & 13.9 & 13.0 & 13.8 & 2.471 & 1.388 & 2.009 & 21 \\
\hline French & 12.8 & 11.7 & 11.7 & 2.074 & 1.329 & 2.123 & 203 \\
\hline German & 13.4 & 12.2 & 12.9 & 2.167 & 1.317 & 2.115 & 1009 \\
\hline Greek & 14.3 & 12.4 & 12.8 & 2.330 & 1.404 & 2.081 & 21 \\
\hline Hawaiian & 12.7 & 9.5 & 12.1 & 2.470 & 1.282 & 2.006 & 6 \\
\hline Irish & 13.4 & 12.6 & 12.8 & 2.219 & 1.401 & 2.098 & 651 \\
\hline Italian & 13.4 & 12.3 & 12.6 & 2.345 & 1.375 & 2.141 & 347 \\
\hline Japanese & 13.4 & 11.9 & 14.1 & 2.093 & 0.907 & 2.194 & 13 \\
\hline Korean & 15.5 & 13.5 & 14.9 & 1.982 & 1.058 & 2.007 & 4 \\
\hline Mexican & 12.3 & 7.4 & 9.0 & 2.015 & 1.114 & 1.808 & 723 \\
\hline Other Hispanic & 13.1 & 10.5 & 11.4 & 2.217 & 1.254 & 1.893 & 102 \\
\hline Polish & 13.4 & 11.8 & 13.0 & 2.242 & 1.389 & 2.164 & 171 \\
\hline Portuguese & 12.0 & 8.8 & 10.5 & 2.159 & 1.267 & 1.984 & 59 \\
\hline Puerto Rican & 11.9 & 7.9 & 9.6 & 2.249 & 1.156 & 1.798 & 170 \\
\hline Russian & 15.0 & 13.6 & 15.3 & 2.666 & 1.486 & 2.324 & 39 \\
\hline Scortish & 14.4 & 13.5 & 13.8 & 2.224 & 1.458 & 2.158 & 86 \\
\hline Welsh & 14.8 & 14.5 & 13.8 & 1.987 & 1.542 & 2.150 & 23 \\
\hline
\end{tabular}

Log Wage of: 
TABLE 8. ESTMMATES OF ETHNIC CAPITAL MONEL IN NLSY

Regression

\begin{tabular}{|c|c|c|c|c|}
\hline \multirow[b]{2}{*}{ Variable } & & & & \\
\hline & (1) & (2) & (3) & (4) \\
\hline \multicolumn{5}{|l|}{ A. Education } \\
\hline Parental Skills & $\begin{array}{c}0.2404 \\
(0.0666)\end{array}$ & $\begin{array}{c}0.2005 \\
(0.0669)\end{array}$ & $\begin{array}{c}0.1745 \\
(0.0718)\end{array}$ & $\begin{array}{c}0.1784 \\
(0.0849)\end{array}$ \\
\hline Ethnic Capital & $\begin{array}{c}0.2004 \\
(0.0465)\end{array}$ & $\begin{array}{c}0.1356 \\
(0.0301)\end{array}$ & $\begin{array}{c}0.0376 \\
(0.0288)\end{array}$ & $\begin{array}{c}0.1480 \\
(0.0504)\end{array}$ \\
\hline $\begin{array}{l}\text { Includes County Fixed Effects } \\
\text { Includes Neighborhood Fixed Effects } \\
\text { Includes Neighborhood Characteristics }\end{array}$ & $\begin{array}{l}\text { No } \\
\text { No } \\
\text { No }\end{array}$ & $\begin{array}{l}\text { Yes } \\
\text { No } \\
\text { No }\end{array}$ & $\begin{array}{r}\text { No } \\
\text { Yes } \\
\text { No }\end{array}$ & $\begin{array}{l}\text { No } \\
\text { No } \\
\text { Yes }\end{array}$ \\
\hline B. Log Wage Rate & & & & \\
\hline Parental Skills & $\begin{array}{c}0.3774 \\
(0.0371)\end{array}$ & $\begin{array}{c}0.2645 \\
(0.0398)\end{array}$ & $\begin{array}{c}0.2500 \\
(0.0418)\end{array}$ & $\begin{array}{c}0.2460 \\
(0.0480)\end{array}$ \\
\hline Ethric Capital & $\begin{array}{c}0.3190 \\
(0.1559)\end{array}$ & $\begin{array}{c}0.3107 \\
(0.1116)\end{array}$ & $\begin{array}{c}0.0458 \\
(0.1331)\end{array}$ & $\begin{array}{c}0.0229 \\
(0.1636)\end{array}$ \\
\hline $\begin{array}{l}\text { Includes County Fixed Effects } \\
\text { Includes Neighborhood Fixed Effects } \\
\text { Includes Neighborhood Characteristics }\end{array}$ & $\begin{array}{l}\text { No } \\
\text { No } \\
\text { No }\end{array}$ & $\begin{array}{l}\text { Yes } \\
\text { No } \\
\text { No }\end{array}$ & $\begin{array}{l}\text { No } \\
\text { Yes } \\
\text { No }\end{array}$ & $\begin{array}{r}\text { No } \\
\text { No } \\
\text { Yes }\end{array}$ \\
\hline \multicolumn{5}{|l|}{ C. Log Wage, Adjusted for Education } \\
\hline Parental Skills & $\begin{array}{c}0.1765 \\
(0.0369)\end{array}$ & $\begin{array}{c}0.1158 \\
(0.0394)\end{array}$ & $\begin{array}{c}0.1214 \\
(0.0410)\end{array}$ & $\begin{array}{c}0.1221 \\
(0.0476)\end{array}$ \\
\hline Ethnic Capital & $\begin{array}{c}0.0759 \\
(0.1571)\end{array}$ & $\begin{array}{c}0.1581 \\
(0.1141)\end{array}$ & $\begin{array}{l}-0.0231 \\
(0.1289)\end{array}$ & $\begin{array}{l}-0.0584 \\
(0.1621)\end{array}$ \\
\hline $\begin{array}{l}\text { Includes County Fixed Effects } \\
\text { Includes Neighborhood Fixed Effects } \\
\text { Includes Neighborhood Characteristics }\end{array}$ & $\begin{array}{l}\text { No } \\
\text { No } \\
\text { No }\end{array}$ & $\begin{array}{l}\text { Yes } \\
\text { No } \\
\text { No }\end{array}$ & $\begin{array}{r}\text { No } \\
\text { Yes } \\
\text { No }\end{array}$ & $\begin{array}{l}\text { No } \\
\text { No } \\
\text { Yes }\end{array}$ \\
\hline $\begin{array}{l}\text { Notes: Standard errors are reported in parenthe } \\
\text { regressions and } 4,261 \text { for the log wage regressi } \\
\text { gender, whether the person is first- or second-g } \\
\text { The neighborhood characteristics included in } \\
\text { wage of parents in the neighborhood. The regre }\end{array}$ & $\begin{array}{l}\text { ns } 4 \text { are the } \\
\text { ons use a ran }\end{array}$ & ge educatic & $\begin{array}{l}\text { education } \\
\text { indicating }\end{array}$ & $\begin{array}{l}\text { imment } \\
\text { orker's age, } \\
\text { in } 1990 . \\
\text { e average log }\end{array}$ \\
\hline
\end{tabular}




\title{
TABLE 9. ESTIMATES OF INTERGENERATIONAL CORRELATION, BY ETHNIC COMPOSITION OF NEIGHBOI $4 I O O D$
}

\author{
Education \\ Log Wage

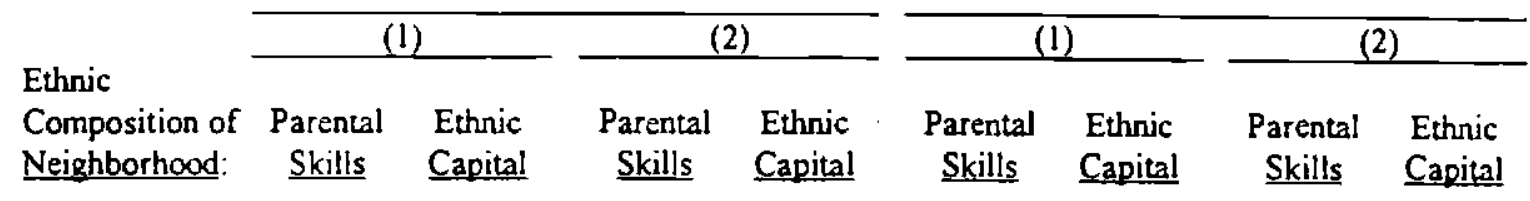 \\ A. 1970 Census \\ Percent with \\ Same Ethnicity:

\begin{tabular}{|c|c|c|c|c|c|c|c|c|}
\hline 0 Percent & $\cdots$ & $\begin{array}{c}0.2458 \\
(0.1195)\end{array}$ & $\rightarrow$ & $\begin{array}{c}0.1467 \\
(0.0781)\end{array}$ & - & $\begin{array}{c}0.2567 \\
(0.1020)\end{array}$ & -.- & $\begin{array}{c}0.1322 \\
(0.0447)\end{array}$ \\
\hline $\begin{array}{l}\text { Between } 0 \text { and } \\
15 \text { Percent }\end{array}$ & $\cdots$ & $\begin{array}{c}0.3206 \\
(0.1410)\end{array}$ & - & $\begin{array}{c}0.2261 \\
(0.0930)\end{array}$ & - & $\begin{array}{c}0.4702 \\
(0.1320)\end{array}$ & -.. & $\begin{array}{c}0.2920 \\
(0.0653)\end{array}$ \\
\hline $\begin{array}{l}\text { Greater Than } \\
\text { is Percent }\end{array}$ & -.. & $\begin{array}{c}0.5325 \\
(0.2338)\end{array}$ & - & $\begin{array}{c}0.2711 \\
(0.2166)\end{array}$ & $\cdots$ & $\begin{array}{c}0.6769 \\
(0.1496)\end{array}$ & -- & $\begin{array}{c}0.3782 \\
(0.1091)\end{array}$ \\
\hline
\end{tabular} \\ B. NLSY \\ Percent with \\ Same Ethricity: \\ $\begin{array}{lcccccccc}\text { Less Than } & 0.2748 & 0.1482 & 0.2071 & 0.0491 & 0.4636 & 0.1850 & 0.3178 & 0.0290 \\ \text { 5 Percent } & (0.0126) & (0.0791) & (0.0131) & (0.0257) & (0.0719) & (0.2085) & (0.0758) & (0.1422) \\ & & & & & & & & \\ \text { Between 5 and } & 0.2933 & 0.2699 & 0.2014 & 0.0439 & 0.4198 & 0.2189 & 0.3292 & 0.0152 \\ \text { 33 Percent } & (0.0116) & (0.0863) & (0.0125) & (0.0267) & (0.0654) & (0.2092) & (0.0737) & (0.1440)\end{array}$ \\ $\begin{array}{lllllllll}\text { Greater Than } & 0.1965 & 0.2998 & 0.1311 & 0.1188 & 0.3828 & 0.2958 & 0.2586 & 0.1429\end{array}$

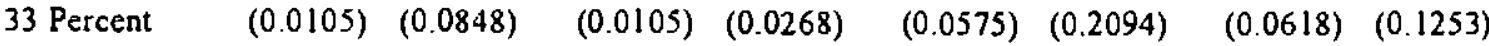 \\ $\begin{array}{lllll}\text { Includes No Nos } & \text { No } & \text { Nos }\end{array}$ \\ Neighborhood \\ Fixed Effects \\ Notes: Standard errors are reported in parentheses. The Census regressions include a second-order porynomial in \\ the worker's age. The NLSY regressions control for the worker's age, gender, whether the person is first- or \\ second-generation, and whether the person is enrolled in school in 1990. The Census regressions have 53,703 \\ observations; the NLSY education regressions have 7,569 observations, and the NLSY log wage regressions have \\ 4,261 observations. The regressions use a random-effects estimator.
}




\section{TABLE 10. INSTRUMENTAL VARLABLE ESTIMATES OF INTERGENERATIONAL CORRELATION IN NLSY}

\begin{tabular}{|c|c|c|c|c|c|c|c|c|}
\hline \multirow[b]{3}{*}{ Model: } & \multicolumn{4}{|c|}{ Education } & \multicolumn{4}{|c|}{ Log Wage } \\
\hline & \multicolumn{2}{|c|}{ (1) } & \multicolumn{2}{|c|}{ (2) } & \multicolumn{2}{|c|}{ (1) } & \multicolumn{2}{|c|}{$(2)$} \\
\hline & $\begin{array}{l}\text { Parental } \\
\text { Skilts }\end{array}$ & $\begin{array}{l}\text { Ethnic } \\
\text { Capital }\end{array}$ & $\begin{array}{c}\text { Parental } \\
\text { Skills } \\
\end{array}$ & $\begin{array}{l}\text { Ethnic } \\
\text { Capital }\end{array}$ & $\begin{array}{c}\text { Parental } \\
\text { Skills } \\
\end{array}$ & $\begin{array}{l}\text { Ethnic } \\
\text { Capital }\end{array}$ & $\begin{array}{c}\text { Parental } \\
\text { Skills } \\
\end{array}$ & $\begin{array}{l}\text { Ethnic } \\
\text { Capital }\end{array}$ \\
\hline All Workers & $\begin{array}{c}0.2781 \\
(0.0111)\end{array}$ & $\begin{array}{c}0.1772 \\
(0.0658)\end{array}$ & $\begin{array}{c}0.1984 \\
(0.0129)\end{array}$ & $\begin{array}{c}0.0885 \\
(0.0510)\end{array}$ & $\begin{array}{c}0.4776 \\
(0.0764)\end{array}$ & $\begin{array}{c}0.3000 \\
(0.2879)\end{array}$ & $\begin{array}{c}0.1366 \\
(0.0978)\end{array}$ & $\begin{array}{c}0.4433 \\
(0.2723)\end{array}$ \\
\hline \multicolumn{9}{|c|}{$\begin{array}{l}\text { Interactions with } \\
\text { Percent of Population } \\
\text { that Has Same Ethnicity }\end{array}$} \\
\hline $\begin{array}{l}\text { Less Than } \\
5 \text { Percent }\end{array}$ & $\begin{array}{c}0.3360 \\
(0.0210)\end{array}$ & $\begin{array}{c}0.1230 \\
(0.0675)\end{array}$ & $\begin{array}{c}0.2912 \\
(0.0242)\end{array}$ & $\begin{array}{c}0.0090 \\
(0.0546)\end{array}$ & $\begin{array}{c}0.5384 \\
(0.1435)\end{array}$ & $\begin{array}{c}0.2516 \\
(0.3010)\end{array}$ & $\begin{array}{c}0.1460 \\
(0.1623)\end{array}$ & $\begin{array}{c}0.3955 \\
(0.2852)\end{array}$ \\
\hline $\begin{array}{l}\text { Between } 5 \text { and } \\
33 \text { Percent }\end{array}$ & $\begin{array}{c}0.3378 \\
(0.0202)\end{array}$ & $\begin{array}{c}0.1076 \\
(0.0670)\end{array}$ & $\begin{array}{c}0.2387 \\
(0.0224)\end{array}$ & $\begin{array}{c}0.0765 \\
(0.0533)\end{array}$ & $\begin{array}{c}0.4209 \\
(0.1379)\end{array}$ & $\begin{array}{c}0.2794 \\
(0.2977)\end{array}$ & $\begin{array}{c}0.1439 \\
(0.1785)\end{array}$ & $\begin{array}{c}0.5579 \\
(0.2465)\end{array}$ \\
\hline $\begin{array}{l}\text { Greater Than } \\
33 \text { Percent }\end{array}$ & $\begin{array}{c}0.1963 \\
(0.0168)\end{array}$ & $\begin{array}{c}0.2357 \\
(0.0660)\end{array}$ & $\begin{array}{c}0.1350 \\
(0.0176)\end{array}$ & $\begin{array}{c}0.1677 \\
(0.0532)\end{array}$ & $\begin{array}{c}0.4744 \\
(0.1154)\end{array}$ & $\begin{array}{c}0.3248 \\
(0.2929)\end{array}$ & $\begin{array}{l}0.2848 \\
(0.1354)\end{array}$ & $\begin{array}{c}0.3436 \\
(0.2805)\end{array}$ \\
\hline $\begin{array}{l}\text { Includes } \\
\text { Neighborhood } \\
\text { Fixed Effects }\end{array}$ & \multicolumn{2}{|c|}{ No } & \multicolumn{2}{|c|}{ Yes } & \multicolumn{2}{|c|}{ No } & \multicolumn{2}{|c|}{ Yes } \\
\hline
\end{tabular}

Notes: Standard errors are reported in parentheses. The Census regressions include a second-order polynomial in the worker's age. The NLSY regressions control for the worker's age, gender, whether the person is first- or second generation, and whether the person is enrolled in school in 1990. The instruments used in the regression include the average skills of the father (either educational attainment or the log occupational wage) as reported by the other siblings in the data; and the average of a set of dummy variables indicating the ethnic background reported by the other siblings. The NLSY education regressions have 3,157 observations; the NLSY log wage regressions have 1,978 observations. The regressions use a random-effects estimator. 
To order any of these papers, see instructions at the end of the list. To subscribe to all NBER Working Papers or the papers in a single area, see instructions inside the back cover. A complete list of NBER Working Papers and Reprints can be accessed on the Internet by using our gopher at nber.harvard.edu.

\begin{tabular}{|c|c|}
\hline Number & Author(s) \\
\hline 4856 & Hans-Wemer Sinn \\
\hline 4857 & $\begin{array}{l}\text { Niko Canner } \\
\text { N. Gregory Mankiw } \\
\text { David N. Weil }\end{array}$ \\
\hline 4858 & $\begin{array}{l}\text { James Dow } \\
\text { Gary Gorton }\end{array}$ \\
\hline 4859 & $\begin{array}{l}\text { Francis X. Diebold } \\
\text { David Neumark } \\
\text { Daniel Polsky }\end{array}$ \\
\hline 4860 & $\begin{array}{l}\text { Michael D. Bordo } \\
\text { Anna J. Schwartz }\end{array}$ \\
\hline 4861 & $\begin{array}{l}\text { David Genesove } \\
\text { Christopher J. Mayer }\end{array}$ \\
\hline 4862 & $\begin{array}{l}\text { Don Fullerton } \\
\text { Diane Lim Rogers }\end{array}$ \\
\hline 4863 & G. William Schwer \\
\hline 4864 & $\begin{array}{l}\text { Enrique G. Mendoza } \\
\text { Assaf Razin } \\
\text { Linda L. Tesar }\end{array}$ \\
\hline 4865 & $\begin{array}{l}\text { Jeffrey A. Frankel } \\
\text { Andrew K. Rose }\end{array}$ \\
\hline 4866 & George J. Borjas \\
\hline 4867 & $\begin{array}{l}\text { Jocl Slemrod } \\
\text { Carl Hansen } \\
\text { Roger Procter }\end{array}$ \\
\hline 4868 & Louis Kaplow \\
\hline 4869 & $\begin{array}{l}\text { Harry Grubert } \\
\text { Joel Slemrod }\end{array}$ \\
\hline$\$ 870$ & Danti Rodrik \\
\hline
\end{tabular}

Title

A Theory of the Welfare State

An Asset Allocation Puzzle

Noise Trading. Delegated Portfolio

Management, and Economic Welfare

Job Stability in the United States

The Specie Standard as a Contingent Rule: Some Evidence for Core and Peripheral

Countries, 1880-1990

Equity and Time to Sale in the Real

Estate Market

Distributional Effects on a Lifetime Basis

Mark-Up Pticing in Mergers and Acquisitions

Effective Tax Rates in Macroeconomics:

Cross-Country Estimates of Tax Rales

on Factor Incomes and Consumption

A Survey of Empirical Research

on Nominal Exchange Rates

Assimilation and Changes in Cohor Quality

Revisited: What Happened to Immigrant

Earnings in the 1980s?

The Seesaw Prixciple in Intemational

Tax Policy

A Note on Subsidizing Gifts

The Effect of Taxes on Investment and Income Shifting to Puerto Rico

What Docs the Political Economy Literature on Trade Policy (Not) Tell Us That We Ought to Know?
$9 / 94$

$9 / 94$

$9 / 94$

$9 / 94$

$9 / 94$ $9 / 94$

$9 / 94$

Date

9/94

$9 / 94$

9/94

$9 / 94$

$9 / 94$

$9 / 94$

$9 / 94$ 
To order any of these papers, see instructions at the end of the list. To subscribe to all NBER Working Papers or the papers in a single area, see instructions inside the back cover. A complete list of NBER Working Papers and Reprints can be accessed on the Internet by using our gopher at nber.harvard.edu.

\begin{tabular}{|c|c|}
\hline Number & Aulhor(s) \\
\hline 4871 & Lars E. O. Svensson \\
\hline 4872 & George J. Borjas \\
\hline 4873 & $\begin{array}{l}\text { José De Gregorio } \\
\text { Federico Sturzenegger }\end{array}$ \\
\hline 4874 & $\begin{array}{l}\text { Brandice J. Canes } \\
\text { Harvey S. Rosen }\end{array}$ \\
\hline 4875 & $\begin{array}{l}\text { Raghuram G. Rajan } \\
\text { Luigi Zingales }\end{array}$ \\
\hline 4876 & $\begin{array}{l}\text { Gene Grossman } \\
\text { Elhanan Helpman }\end{array}$ \\
\hline 4877 & $\begin{array}{l}\text { Gene Grossman } \\
\text { Elhanan Heipman }\end{array}$ \\
\hline 4878 & $\begin{array}{l}\text { C. Keith Head } \\
\text { John C. Ries } \\
\text { Deborah L. Swenson }\end{array}$ \\
\hline 4879 & David M. Cutler \\
\hline 4880 & $\begin{array}{l}\text { Douglas Holtz-Eakin } \\
\text { John R. Penrod } \\
\text { Harvey S. Rosen }\end{array}$ \\
\hline 4881 & $\begin{array}{l}\text { Nouriel Roubini } \\
\text { Gian Maria Milesi-Ferretti }\end{array}$ \\
\hline 4882 & $\begin{array}{l}\text { Nouricl Roubinj } \\
\text { Gian Maria Milesi-Ferretti }\end{array}$ \\
\hline 4883 & $\begin{array}{l}\text { Raquel Fernandez } \\
\text { Richard Rogerson }\end{array}$ \\
\hline 4884 & $\begin{array}{l}\text { R. Glenn Hubbard } \\
\text { Jonathan Skinner } \\
\text { Stephen P. Zeldes }\end{array}$ \\
\hline 4885 & Martin Fcldstein \\
\hline 4886 & $\begin{array}{l}\text { Oliver Hart } \\
\text { John Moore }\end{array}$ \\
\hline
\end{tabular}

Title

Date

Estimating and Interpreting Forward 9/94 Interest Rates: Sweden 1992-1994

Inmigration and Welfare, 1970-1990 $9 / 94$

Credit Markets and the Welfare Costs 10/94 of Inflation

Following in Her Footsteps? Women's Choices 10/94 of College Majors and Faculty Gender Composition

What Do We Know about Capital Structure? 10/94 Some Evidence from International Dato

Foreign Investment with. Endogenous Protection $\quad 10 / 94$

Electoral Competition and Special Interest $\quad 10 / 94$

Politics

The Altraction of Foreign Manufacturing lnvestments: Investment Promotion and Agglomerntion Economies

Market Fuilure in Small Group Health Insurance $\quad$ 10/94

Health Insurance and the Supply of $\quad 10 / 94$

Entrepreneurs

Taxation and Endogenous Growth in Open

$10 / 94$

Economies

Optimal Taxalion of Human and Physical Capital $\quad 10 / 94$ in Endogenous Growth Models

Public Education and Income Distribution: A $\quad 10 / 94$ Quantilative Evaluation of Education Finance Reform

Precautionary Saving and Social Insurance $\quad 10 / 94$

Fiscal Policies, Capital Formalion and Capitalism $\quad 10 / 94$

Debt and Seniority: An Anslysis of the Role 10/94 of Hard Claims in Constraining Management 
To order any of these papers, see instructions at the end of the list. To subscribe to all NBER Working Papers or the papers in a single area, see lostructions inside the back cover. A complete list of NBER Working Papers and Reprints can be accessed on the Internet by uslng our gopher at nber.harvard.edu.

Number

4887

4888

4889

4890

4891

4892

4893

4895

4896
Author(s)

Ricardo J. Caballero Edurdo M.R.A. Engel

Martin Feldstein

James H. Stock

Mark Hooker Michsel Knetter

John $R$. Graham Campbell R. Harvey

W. Kip Viscusi

AJan M Taylor

Maurice Obstfeld Kenneth Rogoff

Michael M. Knetter

Peter Diamond

Lawrence H. Goulder

A. Lans Bovenberg Lawrence H. Goulder

Barry Eichengreelı Andrew K. Rose Charles Wyplosz

Shane Greenstein

Orazio P. Attanasio Thomas C. DeLeire

Timothy F. Bresnahan Shane Greenstein
Title

Date

Explaining Investment Dynamics in U.S. Manufacturing: A Generalized $(S, s)$ Approach

Measuring Money Growth When Financial Markets Are Changing

Unemployment Effects of Military Spending: Evidence from a Panel of States

Market Tuming Ability and Volatility Implied in Investment Newsletters" Asset Allocation Recommendations

Cigarette Taxation and the Social Consequences of Smoking

Domestic Saving and Internstional Capital Flows Reconsidered

$10 / 94$

$10 / 94$

$10 / 94$

$10 / 94$

$10 / 94$

The Intertemporal Approach to the Current Account

$10 / 94$

$10 / 94$

Why Are Retail Prices in Japan So High?: Evidence from German Export Prices

Insulation of Pensions fram Political Risk

$10 / 94$

Environmental Taxation and the "Double

$10 / 94$

Dividend": A Reader's Guide

Optimal Environmental Taxation in the Presence

$10 / 94$ of Other Taxes: General Equitibrium Analyses

Speculative Allacks on Pegged Exchange Rates: An Empirical Exploration with Special Reference to the European Monetary System

From Superminis to Supercomputers: Estimating Surplus in the Computing Market

IRAs and Household Saving Revisited:

Some New Evidence

The Competitive Crash in Large-Scale Commercial Computing 
To order any of these papers, see instructions at the end of the list. To subscribe to all NBER Working Papers or the papers in a single area, see instructions inside the back cover. A complete list of NBER Working Papers and Reprints can be accessed on the Internet by using our gopber at nber.harvard.edu.

\begin{tabular}{|c|c|c|c|}
\hline Number & Author(s) & Title & Dale \\
\hline 4902 & Joel Slemrod & Free Trade Taxation and Protectionist Taxation & $10 / 94$ \\
\hline 4903 & $\begin{array}{l}\text { Assaf Razin } \\
\text { Efraim Sadka }\end{array}$ & $\begin{array}{l}\text { Resisting Migration: The Problems of Wage } \\
\text { Rigidity and the Social Burden }\end{array}$ & $10 / 94$ \\
\hline 4904 & $\begin{array}{l}\text { Ernsı R. Bernd1 } \\
\text { Linda Bui } \\
\text { David Reiley } \\
\text { Glen Urban }\end{array}$ & $\begin{array}{l}\text { The Roles of Marketing. Product Quality and } \\
\text { Price Competition in the Growth and } \\
\text { Composition of the U.S. Anti-Ulcer } \\
\text { Drug Industry }\end{array}$ & 10,94 \\
\hline 4905 & $\begin{array}{l}\text { Thomas C. Kinnaman } \\
\text { Don Fullerion }\end{array}$ & $\begin{array}{l}\text { How a Fee Per-Unit Garbage Affects } \\
\text { Aggregate Recycling in a Model with } \\
\text { Heierogeneous Households }\end{array}$ & $10 / 94$ \\
\hline 4906 & Daniel S. Hamermesh & $\begin{array}{l}\text { Aging and Productivity, Rationality and } \\
\text { Matching: Evidence from Economists }\end{array}$ & $10 / 94$ \\
\hline 4907 & $\begin{array}{l}\text { Kooyul Jung } \\
\text { Yong-Cheol Kim } \\
\text { René Ml. Stulz }\end{array}$ & $\begin{array}{l}\text { Investment Opportunities, Managerial } \\
\text { Discretion, and the Security Issue } \\
\text { Decision }\end{array}$ & $10 / 94$ \\
\hline 4908 & $\begin{array}{l}\text { Jun-Koo Kang } \\
\text { René M. Stulz }\end{array}$ & $\begin{array}{l}\text { How Different is Japanese Corporate } \\
\text { Finance? An Investigation of the } \\
\text { Information Content of New Security Issues }\end{array}$ & $10 / 94$ \\
\hline 4909 & Robert J. Barro & Democracy and Growth & $10 / 94$ \\
\hline 4910 & Richard B. Freeman & Crime and the Job Market & $10 / 94$ \\
\hline 4911 & Rebecca M. Blank & The Dynamics of Part-Time Work & $11 / 94$ \\
\hline 4912 & George J. Borjas & $\begin{array}{l}\text { Ethnicity, Neighborhoods, and Human Capital } \\
\text { Extcmalities }\end{array}$ & $11 / 94$ \\
\hline
\end{tabular}

Copies of the above working papers can be obtained by sending $\$ 5.00$ per copy (plus $\$ 10.00$ per order for postage and handling for all locations outside the continental U.S.) to Working Papers, NBER, 1050 Massachusetts Avenue, Cambridge, MA 02138-5398. Advance payment is required on all orders. Payment may be made by check or credit card. Checks should be made payable to the NBER and must be in dollars drawn on a U.S. bank. If paying by credit card. include the cardholder's name, account number and expiration date. For all mail orders, please be sure to include your return address and telephone number. Working papers may also be ordered by telephone $(617-868-3900)$, or by fax (617-868-2742). 


\section{National Bureau of Economic Research}

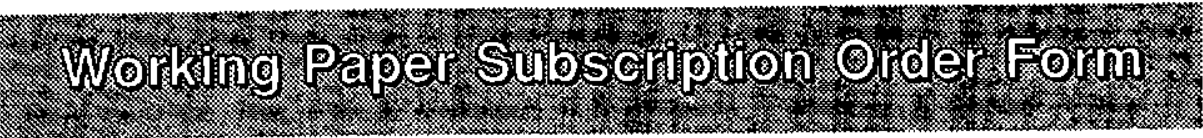

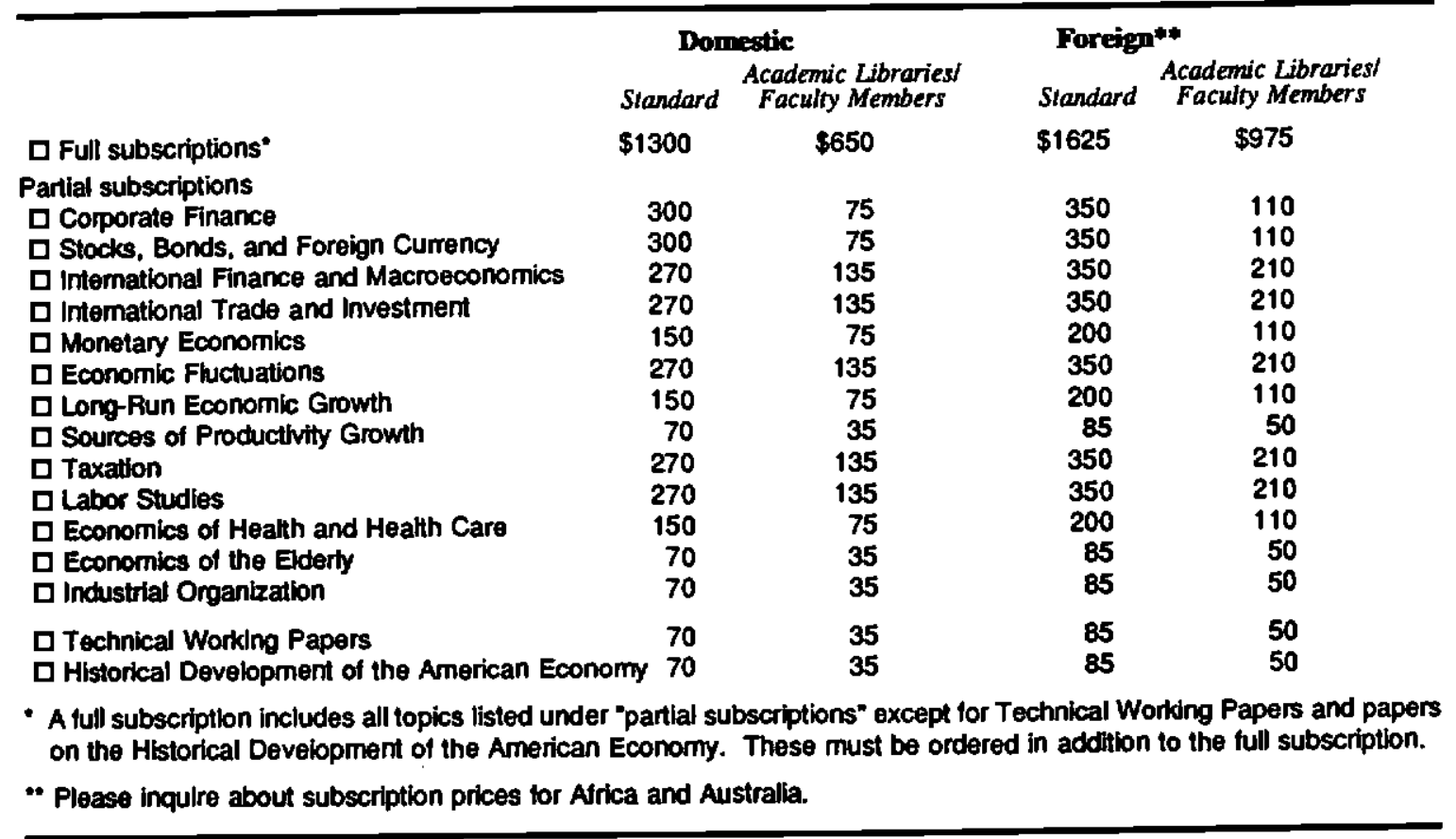

\section{PAYMENT OPTIONS}

$\square$ YES! Please begin my subscription to the NBER Working Paper Series. I have indicated above which papers I would like to receive.

By Phone: (617) 868-3900

By FAX: (617) 868-2742

By Mail: Publicationo Department

National Bureau of Economic Research

1050 Massachusetts Ave.

Cambridge, MA 02138

$\square$ Payment in the amount of enclosed.

D Please charge my: $\square$ VISA $\square$ MasterCard

Cand Number:

Card expiration:

Signahure:
Please mail my papers to this address:

Name

Address

Phone:

FAX: 